\title{
Coordination of Immune-Stroma Crosstalk by IL-6 Family Cytokines
}

\author{
Nathaniel R. West* \\ Department of Cancer Immunology, Genentech, South San Francisco, CA, United States
}

Stromal cells are a subject of rapidly growing immunological interest based on their ability to influence virtually all aspects of innate and adaptive immunity. Present in every bodily tissue, stromal cells complement the functions of classical immune cells by sensing pathogens and tissue damage, coordinating leukocyte recruitment and function, and promoting immune response resolution and tissue repair. These diverse roles come with a price: like classical immune cells, inappropriate stromal cell behavior can lead to various forms of pathology, including inflammatory disease, tissue fibrosis, and cancer. An important immunological function of stromal cells is to act as information relays, responding to leukocyte-derived signals and instructing leukocyte behavior in kind. In this regard, several members of the interleukin-6 (IL-6) cytokine family, including IL-6, $I L-11$, oncostatin $M(O S M)$, and leukemia inhibitory factor (LIF), have gained recognition

OPEN ACCESS

Edited by:

Teruki Dainichi,

Kyoto University, Japan

Reviewed by:

Carl D. Richards,

McMaster University, Canada

Nathan Karin,

Technion Israel Institute of

Technology, Israel

*Correspondence:

Nathaniel R. West

west.nathanie/@gene.com

Specialty section:

This article was submitted to Immunological Tolerance and

Regulation,

a section of the journal

Frontiers in Immunology

Received: 28 February 2019

Accepted: 29 April 2019

Published: 15 May 2019

Citation:

West NR (2019) Coordination of Immune-Stroma Crosstalk by IL- 6

Family Cytokines.

Front. Immunol. 10:1093.

doi: 10.3389/fimmu.2019.01093 as factors that mediate crosstalk between stromal and immune cells, with diverse roles in numerous inflammatory and homeostatic processes. This review summarizes our current understanding of how IL-6 family cytokines control stromal-immune crosstalk in health and disease, and how these interactions can be leveraged for clinical benefit.

Keywords: stromal cells, cytokines, inflammation, fibrosis, immune

\section{THE DIVERSE ROLES OF STROMAL CELLS IN IMMUNITY AND INFLAMMATION}

The term "stroma" refers to the non-parenchymal components of tissues that form a supportive matrix in which parenchymal cells reside (1). While a confusingly broad array of cell types have been described as "stromal cells," in this review they are defined as non-hematopoietic, non-epithelial mesenchymal cells, including fibroblasts, myofibroblasts, bone marrow stromal cells, and the specialized fibroblast-like stromal cells of secondary lymphoid organs. Other mesenchymal populations such as endothelial cells, adipocytes, and muscle cells, while of great interest, are largely omitted from this discussion for the sake of brevity and clarity. Long considered to be mere structural entities without specialized functions, an explosion of data in the last two decades has established stromal cells as key regulators of both protective and pathological immune responses (2).

Regulation of immune function by stromal cells has been most extensively studied in the context of secondary lymphoid organs. First identified in 1992, podoplanin (PDPN) ${ }^{+}$fibroblastic reticular cells (FRC) form a dense reticular network in lymph nodes that facilitates leukocyte migration and antigen presentation (2-5). By producing soluble chemokines, cytokines, and other factors-such as CCL19 (C-C motif chemokine ligand 19), CCL21, and IL-7 (interleukin 7)-FRC are crucial for controlling leukocyte recruitment, survival, and proliferation. FRC-like stromal cells play similar roles in other lymphatic tissues, such as in tertiary lymphoid organs of the intestinal mucosa $(6,7)$. 
In non-lymphoid tissues, stromal cells can exert similar effects to those of the secondary lymphoid organs by acting as scaffolds for leukocyte migration and by producing a diverse array of cytokines and chemokines (2).

Importantly, the immunological functions of stromal cells can vary substantially depending on their host organ and physiological context. For example, lymph node FRC recruit CCR7 (C-C chemokine receptor type 7$)^{+} \mathrm{T}$ cells (naïve and central memory) and $\mathrm{CCR}^{+}$dendritic cells (DC) to lymph nodes by producing the chemokines CCL19 and CCL21, as well as the pro-survival cytokines IL-7 and IL15 , thereby coordinating $\mathrm{T}$ cell activation and maintenance (4). In contrast, stromal cells in peripheral tissues generally lack expression of CCL19 and CCL21; accordingly, naïve and central memory $\mathrm{T}$ cells are infrequent in the periphery. However, expression of various pattern recognition and cytokine receptors by non-lymphoid tissue stromal cells allows them to sense microbial molecules and endogenous danger signals $(1,8,9)$. In response, they produce chemokines [including CCL20 and CXCL10 (C-X-C motif chemokine ligand 10)] that attract effector $\mathrm{T}$ cells to sites of inflammation. Furthermore, inducible expression of leukocyte adhesion molecules including ICAM-1 (intercellular adhesion molecule 1) and VCAM-1 (vascular cell adhesion molecule 1) allows tissue-resident stromal cells to further influence the balance between leukocyte recruitment, retention, and recirculation (1, 2, 9). Finally, stromal cells contribute directly to immune response resolution and tissue repair, the latter being one of their best studied functions. Examples of "pro-resolution" factors produced by stromal cells include NOS2 (nitric oxide synthase 2) and NO (nitric oxide), which are released by lymph node FRC to constrain T cell proliferation (10-12), and IDO1 (indoleamine 2,3-dioxygenase 1) produced by peripheral stromal cells, which similarly limits $\mathrm{T}$ cell proliferation by depleting the critical $\mathrm{T}$ cell metabolite tryptophan $(13,14)$. Thus, stromal cells in different tissues collectively regulate the strength, quality, and duration of immune responses via diverse and complementary mechanisms.

As with most immunological processes, communication between stromal and immune cells is highly dependent on cytokines. Stromal cells bear receptors to a variety of biologically diverse cytokines that represent virtually all branches of innate and adaptive immunity, including innate inflammatory cytokines [e.g., TNF (tumor necrosis factor) and IL-1 $\beta$ ], Th1 cytokines [e.g., IFN- $\gamma$ (interferon gamma)], Th2 cytokines (e.g., IL-13), Th17 cytokines (e.g., IL-17A), and tolerogenic cytokines [e.g., TGF- $\beta$ (transforming growth factor beta)] $(7,9,15,16)$. In turn, stromal cells can be prodigious producers of other cytokines and chemokines, such as IL-6 $(1,2,7,9)$. In recent years, cytokines of the IL-6 family have gained increasing attention for their roles in various homeostatic and pathological processes, which in many cases can be attributed to their ability to co-ordinate immunestroma crosstalk. This review aims to provide a focused update on the contributions of IL-6 family members to immunestromal interactions.

\section{AN OVERVIEW OF THE IL-6 CYTOKINE FAMILY}

The IL-6 family includes IL-6, IL-11, IL-27, IL-31, oncostatin M (OSM), leukemia inhibitory factor (LIF), ciliary neurotrophic factor (CNTF), cardiotrophin 1 (CT-1), and cardiotrophinlike cytokine factor 1 (CLCF1) $(17,18)$. With the exception of IL-27, which is a heterodimeric protein comprised of IL27p28 and EBI3 (Epstein-Barr virus-induced gene 3) (19), IL-6 family members are compact 4 -helix bundle cytokines made from a single polypeptide. Glycoprotein 130 (gp130, encoded by the IL6ST gene) is a crucial receptor subunit utilized by all members of the IL-6 family except IL-31. While gp130 expression is relatively ubiquitous in a wide variety of tissues and organs, cell-type specificity for different IL-6 family members is bestowed by the more restricted expression patterns of ligandspecific co-receptors, including IL-6R (IL-6 receptor), IL-11R (IL-11 receptor), IL-27R $\alpha$ (IL-27 receptor alpha), OSMR (OSM receptor), LIFR (LIF receptor), and CNTFR $\alpha$ (CNTF receptor alpha). Three distinct forms of receptor-ligand complexes have been described (Figure 1). First characterized was that of IL-6, which engages IL-6R along with two subunits of gp130. Intriguingly, although this implies the formation of a trimeric complex, a series of cooperative interactions can ultimately produce an interlocked hexamer comprised of two subunits each of IL-6, IL-6R, and gp130 (20). A similar structure is likely formed in response to IL-11/IL-11R interaction $(21,22)$. In this arrangement, only gp130 drives signal transduction, due to an absence of intracellular signaling motifs in IL-6R and IL-11R. In contrast, OSMR, LIFR, and IL-27R $\alpha$ form heterodimers with gp130 in the presence of their cognate ligands (23-28). Unlike IL-6R and IL-11R, OSMR, LIFR, and IL-27R $\alpha$ are capable of driving signal transduction via their own suite of signaling motifs. Finally, CNTF and CLCF1 drive formation of a trimeric complex that includes gp130, LIFR, and CNTFR $\alpha$ (29-31). The gp130-independent outlier of the family, IL-31, engages a heterodimeric complex of IL$31 \mathrm{R} \alpha$ (previously known as gp130-like receptor) and OSMR (18). Notably, while mouse OSM binds with high affinity only to the gp130/OSMR heterodimer, human and rat OSM can bind with high affinity to either gp130/OSMR or gp130/LIFR heterodimers (32-34). Thus, in rats and humans, manipulation of LIFR would be expected to affect both OSM and LIF signaling (as well as CLCF1, CT-1, and CNTF), while manipulation of OSMR would influence OSM and IL-31 signaling. As a corollary, changes in human or rat OSM bioavailability would influence cells that express OSMR and/or LIFR, while changes in LIF or IL-31 would affect only LIFR- or IL-31R $\alpha$-expressing cells, respectively.

All members of the IL-6 family drive signal transduction via receptor-associated Janus kinases (primarily JAK1 and JAK2), which phosphorylate a variety of conserved tyrosine residues in the cytoplasmic domains of signaling receptor subunits (gp130, OSMR, LIFR, IL-27R $\alpha$, and IL-31R $\alpha)(17,18,35)$. Several downstream signaling pathways are activated in response, including signal transducer and activator of transcription 


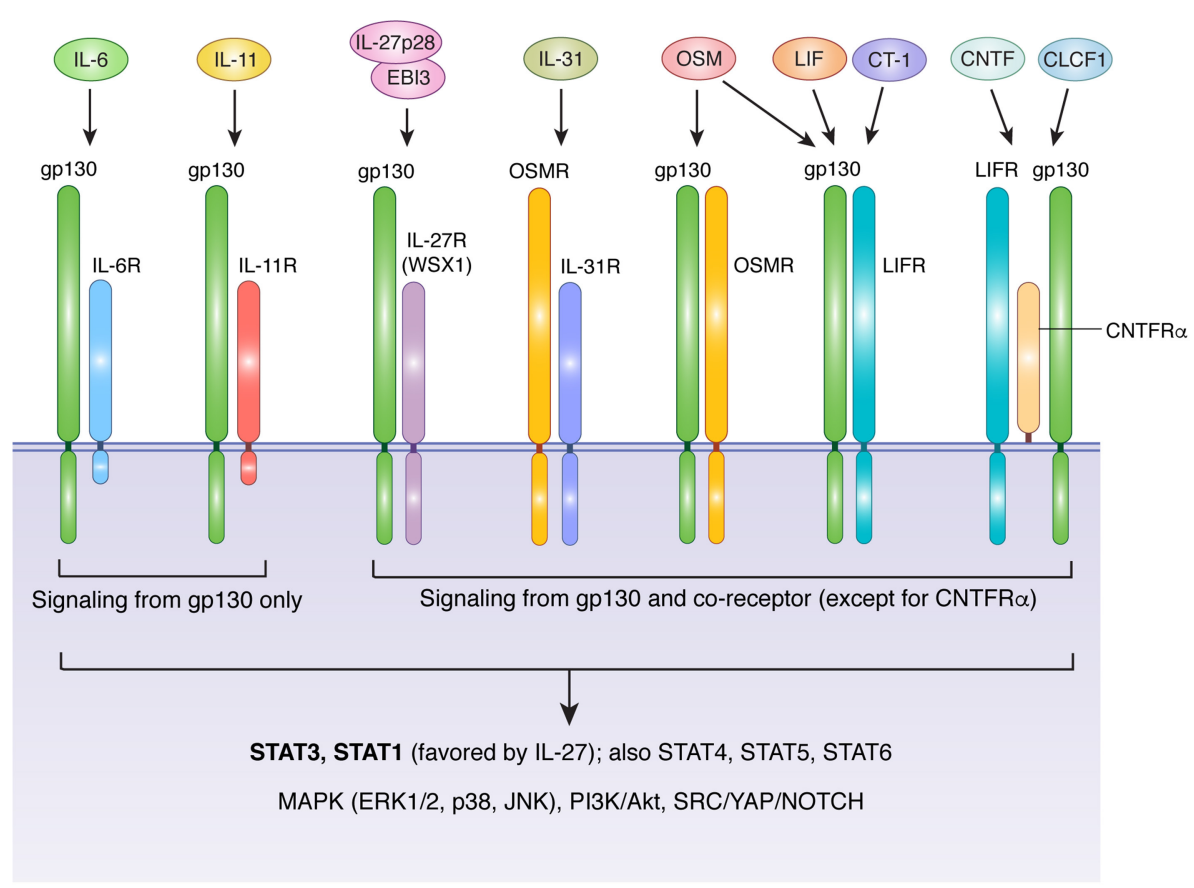

FIGURE 1 | Receptor usage of IL-6 family cytokines. With the exception of IL-31, IL-6 family cytokines transduce signals via receptor complexes that include gp130 and one or more additional ligand-specific subunits. IL-6 and IL-11 signaling requires IL-6R and IL-11R, respectively. The cytoplasmic domains of these receptor are short and lack signaling motifs, making gp130 the sole source of signal transduction downstream of IL-6 and IL-11. The heterodimeric cytokine IL-27 (comprised of IL-27p28 and EBI3) requires a complex of gp130 and IL-27RA. LIF and CT-1 use a heterodimeric complex of gp130 and LIFR, while CNTF and CLCF1 signal via a trimeric complex of gp130, LIFR, and CNTFR $\alpha$, a GPI-anchored protein that does not directly contribute to signaling beyond facilitation of ligand binding. OSM displays species-specific receptor usage. In humans and rats, OSM signals via either gp130/OSMR or gp130/LIFR complexes, while in mice OSM is primarily recognized by OSMR. IL-31 does not require gp130, and instead uses a complex of OSMR and IL-31R. Aside from IL-6R, IL-11R, and CNTFR $\alpha$, all receptors in the IL-6 family are capable of directly activating signal transduction in response to ligand binding. IL-6 family cytokines employ classical JAK-mediated signaling. Major downstream mediators include STAT3 (the main STAT for all except IL-27), STAT1 (activated preferentially by IL-27 and to a lesser extent by other IL-6 family members), additional STATs that depend on cell type and physiological context (including STATs 4, 5, and 6), the MAPK cascade, PI3K/Akt/mTOR signaling, and $\mathrm{SRC/YAP/NOTCH}$ signaling. Akt, protein kinase B; CLCF1, cardiotrophin-like cytokine factor 1; CNTF, ciliary neurotrophic factor; CT-1, cardiotrophin 1; EBI3, Epstein-Barr virus induced 3; ERK, extracellular signal-regulated kinase; gp130, glycoprotein 130, also known as IL-6 signal transducer; IL, interleukin; IL-6R, IL-6 receptor; IL-11R, IL-11 receptor; IL-27RA, IL-27 receptor; CNTFR $\alpha$, CNTF receptor; LIF, leukemia inhibitory factor; LIFR, LIF receptor; MAPK, mitogen activated protein kinase; JAK, janus kinase; JNK, c-jun n-terminal kinase; mTOR, mammalian target of rapamycin; OSM, oncostatin M; OSMR, OSM receptor; PI3K, phosphatidylinositol-3-kinase; STAT, signal transducer and activator of transcription; SRC, Proto-oncogene tyrosine-protein kinase Src; YAP, yes-associated protein.

(STAT) proteins (including STAT1, STAT3, STAT4, STAT5, and STAT6), the mitogen-activated protein kinase (MAPK) cascade, the phosphatidylinositol-3-kinase (PI3K)/Akt pathway, and the SRC/YAP/NOTCH pathway (Figure 1). While signal transduction by individual IL- 6 family members is broadly similar, the relative strength of activation of specific pathways can differ depending on the cytokine, cell type, and physiological context. For example, unlike gp130, OSMR efficiently recruits the adapter protein SHC, allowing OSM to drive more potent activation of the MAPK pathway than IL-6, which signals via SHP-2 bound to gp130 $(35,36)$. Similarly, although STAT3 is generally considered to be the dominant STAT protein activated by the IL- 6 family, IL-27 preferentially activates STAT1 (37). Further complexity is provided by the capacity of IL-6, IL-11, and CNTF to signal via soluble receptor forms in a process known as trans signaling. In this process, soluble versions of IL-6R, IL-11R, or CNTFR $\alpha$ are produced either through proteolytic cleavage of membrane-bound receptors, or via expression of alternatively spliced mRNA; in either case, the soluble receptor form can dimerize with its cognate ligand in solution, and subsequently produce a functional signaling complex in association with membrane-bound gp130 $(18,38-40)$. Cells thus require only gp130 to be sensitive to trans signaling, which allows many cell types that lack IL-6R, IL-11R, or CNTFR $\alpha$ to respond to these cytokines. In the case of IL-6, trans signaling is thought to be a critical mechanism by which IL- 6 promotes disease pathogenesis, particularly arthritis and colorectal cancer $(18,41,42)$. Thus, while many similarities exist between IL-6 family cytokines, differences in their receptor usage, signal transduction profiles, and patterns of receptor expression collectively foster a substantial degree of functional pleiotropy. Indeed, IL-6 family members influence cell survival, proliferation, differentiation, metabolism, and migration, thus contributing to a plethora of physiological processes that are critical for both homeostasis and pathology. 


\section{EXPRESSION OF IL-6 FAMILY CYTOKINES BY STROMAL CELLS}

Although some members of the IL-6 family are produced primarily by hematopoietic cells (notably OSM and IL-27), stromal cells can be important sources of several others, including IL-6, IL-11, and LIF. Diverse factors appear to regulate the expression of these cytokines by stromal cells, including microbial sensing, detection of endogenous alarmins, stimulation by other cytokines (including those within the IL-6 family itself), and cell stress (Figure 2). Although these inputs are known drivers of cytokine production, the critical drivers in vivo, particularly under physiological conditions, are rarely well defined.

In response to infection or an inflammatory challenge, IL-6 production is rapidly increased by stromal cells. Depending on their location and the nature of the challenge, this could be due to direct sensing of danger signals, responses to other inflammatory cytokines, or both. As an NF- $\mathrm{B}$ (nuclear factor kappa B) response gene (43), IL-6 is induced by stromal cells downstream of several pattern recognition receptors including, but probably not limited to, toll-like receptor (TLR)2, TLR4, and NOD2 (nucleotide binding oligomerization domain 2) (44-46).
The NF- $\kappa$ B activating cytokines IL-1 $\beta$, IL-17A, and TNF (tumor necrosis factor alpha) are also potent inducers of stromal IL-6 production, and can do so in synergy with one another $(43,47-$ 54). Although NF-кB is thought to be the dominant driver of IL-6 production downstream of these cytokines, contributions by MAPK signaling have also been observed. Indeed, signaling by alternative pathways such as the MAPK and PI3K cascades may underlie the ability of cytokines like OSM $(55,56)$, IL-4 (49), and TGF- $\beta(54,57)$ to promote stromal IL-6 expression, since these are not classical activators of NF- $\kappa$ B. Beyond cytokines and danger signals, cadherin-11 (CDH11), a mesenchymal cadherin that engages in homophilic interactions between adjacent cells, has also been shown to drive IL-6 production via NF- $\kappa \mathrm{B}$ and MAPK signaling (53). Indeed, blockade of CDH11 attenuates inflammation in mouse models of arthritis, an effect that may be due in part to reduced IL- 6 production by $\mathrm{CDH} 11^{+}$synovial fibroblasts (53). Finally, IL-6 is a well-known product of the senescence-associated secretory phenotype (SASP) in fibroblasts, a feature associated with aging and cancer (58). Indeed, IL-6 produced by prostate tumor fibroblasts in response to metabolic stress has been proposed to mediate malignant progression (59).

Less is known about the regulation of LIF and IL-11 expression by stromal cells, but the mechanisms involved may be similar

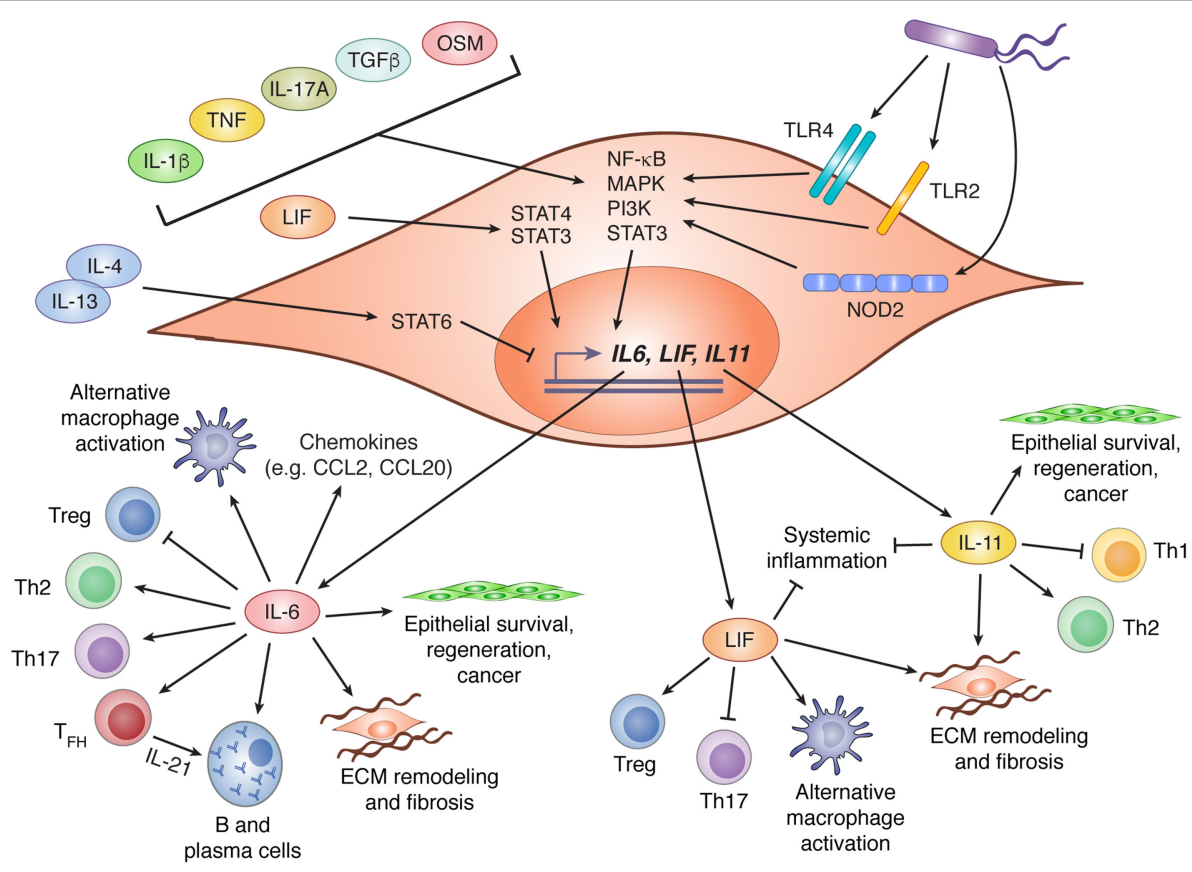

FIGURE 2 | IL-6 family cytokine production by stromal cells and their biological effects. Stromal cells are important contributors to production of three members of the IL-6 family: IL-6, LIF, and IL-11. Expression of these cytokines is regulated by various stimuli including recognition of bacterial products via TLR2, TLR4, or NOD2, and diverse cytokines that drive activation of NF-kB, MAPK, PI3K, and STAT3. LIF has been shown to promote IL-6 expression via STAT4 signaling, while IL-4 and IL-13 can suppress LIF and IL-11 expression through activation of STAT6. Following production by stromal cells, IL-6, LIF, and IL-11 can influence diverse biological processes including $\mathrm{CD}_{4}{ }^{+} \mathrm{T}$ cell polarization, regulation of chemokine production, promotion of alternative macrophage differentiation, and tissue remodeling through effects on stromal and epithelial cells. In this figure, arrows indicate stimulatory effects, and capped lines indicate inhibitory effects. All processes illustrated are described further in the main text. CCL, C-C motif chemokine ligand; ECM, extracellular matrix; IL, interleukin; LIF, leukemia inhibitor factor; MAPK, mitogen activated protein kinase; NF-kB, nuclear factor kappa B; NOD2, nucleotide-binding oligomerization domain-containing protein 2; OSM, oncostatin M; PI3K, phosphatidylinositol-3-kinase; STAT, signal transducer and activator of transcription; $\mathrm{TFH}_{\mathrm{FH}}$, T follicular helper cell; TGF $\beta$, transforming growth factor beta; Th, T helper; TLR, toll-like receptor; Treg, regulatory T cell. 
to those of IL-6. Like IL-6, LIF and IL-11 expression by stromal cells can be induced by IL- $1 \beta$, TNF, and TGF- $\beta$ (60-64). Notably, induction of both IL-11 and LIF in response to TGF- $\beta$ stimulation of cancer-associated fibroblasts is thought to promote tumor progression $(61,62)$. Intriguingly, IL-4 and IL-13 were shown to counteract TNF and IL-1 $\beta$-induced expression of LIF and IL-11, but not IL-6, by gingival fibroblasts (64). This effect was dependent on STAT6, and provides a potential mechanism for selective modulation of individual IL-6 family members.

\section{RESPONSIVENESS OF STROMAL CELLS TO IL-6 FAMILY CYTOKINES}

Stromal cells express the necessary receptor subunits to respond to the majority of gp130-dependent IL-6 family cytokines. In general, gp130 and OSMR are ubiquitously expressed by stromal cells from essentially all anatomical locations studied thus far. OSM is therefore a major activating factor of stromal cells, as well as various other mesenchymal populations including endothelial cells, muscle cells, adipocytes, and osteoblasts (34, $56,65)$. Expression of other ligand-specific receptor subunits is more variable and depends on the cell type, anatomical location, and physiological context. IL-6R, for example, tends to be expressed at relatively low levels, and stromal cells are correspondingly less sensitive to classical IL-6 signaling than OSM. Indeed, expression of OSMR mRNA in human colon fibroblasts is roughly 10x higher than that of IL-6R (55). However, inflammatory conditions that yield soluble IL-6R can increase stromal cell sensitivity to IL-6 due to trans signaling. Responsiveness of stromal cells to LIF appears to vary widely depending on anatomical location. For example, LIF induces contractile and inflammatory phenotypes in dermal and synovial fibroblasts, respectively, but has little effect on colon fibroblasts $(55,62,63,66)$. Sensitivity of stromal cells to IL-11 and IL-27 has also been documented (67-73). In contrast, IL-31R $\alpha$ does not seem to be expressed by most stromal cells at physiologically relevant levels $(74,75)$.

\section{CONTROL OF INFLAMMATION AND ADAPTIVE IMMUNITY BY THE IL-6-STROMA AXIS}

Exposure of stromal cells to factors such as microbial ligands or inflammatory cytokines can drive IL-6 production during both acute and chronic inflammation. Following infection of mice by Toxoplasma gondii, for example, IL-6 expression was shown to be elevated in a population of bone marrow stromal cells characterized by high VCAM-1 and low CD146 expression, and stroma-derived IL- 6 was required for the increased myelopoiesis that occurs as part of the host response to infection (76). Bone marrow stromal cells also induce IL-6 in response to viral infections such as CMV (cytomegalovirus) (77). During Helicobacter hepaticus-driven colitis in mice, non-hematopoietic stromal cells are the dominant intestinal producers of IL-6, with expression levels that substantially exceed those of $\mathrm{MHC}^{-\mathrm{II}^{+}}$ myeloid cells (55). Interestingly, IL-6 expression may be a feature of specific intestinal stromal cell subsets with distinct ontogeny or activation states. For example, human OSMR high intestinal stromal cells were found to be enriched in IL-6 expression relative to their OSMR ${ }^{\text {low }}$ counterparts (55), consistent with the well-established ability of OSM to induce IL-6 expression in mesenchymal cells (78-86). Single-cell RNA-sequencing has similarly revealed substantial heterogeneity in the intestinal stromal cell compartment. High IL-6 expression is enriched in a stromal cell subset that is rare in healthy individuals, but dramatically expanded in patients with inflammatory bowel disease (IBD) (87). Notably, these cells were further characterized by expression of a variety of additional immunostimulatory molecules, including IL-33 and the FRC-associated chemokines CCL19 and CCL21, implying a specialized role in immune regulation (87). Notably, a disease-associated single nucleotide polymorphism (SNP) in the human IL6 promoter was shown to control production of IL- 6 by fibroblasts, but had no effect on IL-6 expression by $\mathrm{CD} 14^{+}$monocytes, suggesting that host genetics can also play an important role in determining stromal IL-6 output (88).

Following initiation of acute inflammation, IL-6 can act on several cell types to shape the quality of the ensuing immune response. For example, IL-6 controls the balance between inducible regulatory $\mathrm{T}$ cell (Treg) and Th17 differentiation following activation of naïve $\mathrm{CD} 4^{+} \mathrm{T}$ cells (41). Although stromal cells have not conclusively been demonstrated to contribute to this process, FRC-derived IL-6 has been suggested to support the development and maintenance of B cell responses. Medullary FRC were shown to be important regulators of plasma cell homeostasis, in part by producing the plasma cell survival factor IL-6 $(89,90)$. IL-6 is also necessary for the differentiation of follicular helper $\mathrm{T}$ cells $\left(\mathrm{T}_{\mathrm{FH}}\right)$, which drive the maturation of $\mathrm{B}$ cells and the generation of protective antibody responses $(91,92)$. Importantly, IL- 6 induces production of IL- 21 by $\mathrm{T}_{\mathrm{FH}}$ cells, which is critical for both $\mathrm{T}_{\mathrm{FH}}$ maintenance and plasma cell differentiation in germinal centers $(93,94)$. Publicly available data provided by the ImmGen project suggest that FRC constitutively express IL-6, and do so at levels that far exceed those of other lymph node-resident cell types (95). Thus, FRC-derived IL-6 is likely to be a central linchpin in the regulation of both $\mathrm{T}$ cell and $\mathrm{B}$ cell responses in secondary lymphoid organs.

In inflamed peripheral tissues, IL-6 controls the temporal switch from recruitment of granulocytes to preferential recruitment of mononuclear cells by modulating chemokine and cytokine production in local mesenchymal cells, including the suppression of TNF and IL- $1 \beta$ production, possibly via STAT3mediated repression of NF-кB signaling $(96,97)$. IL-6 promotes the differentiation of monocytes into macrophages rather than dendritic cells in vitro, but genetic IL-6 deficiency does not affect dendritic cell frequencies in vivo (98-101). However, IL-6 appears to mediate alternative macrophage differentiation in vivo and inhibits inflammatory cytokine production and microbicidal activity by macrophages (102-105). IL-6 can also promote survival and regeneration of damaged epithelia during inflammatory challenges, a feature that can be subverted to promote cancer progression (106). Thus, while IL-6 is important for initiation of immune responses, it also promotes resolution 
of inflammation and tissue repair $(54,62)$. Notably, IL-6 protects mice from the lethal inflammatory effects of Staphylococcal enterotoxin B (SEB; a model of toxic shock), in direct contrast with TNF (107).

Although IL-6 is an important regulator of physiological immune responses, excess or chronic IL-6 production can promote inflammatory or fibrotic pathology. IL-6 has been implicated in a variety of inflammatory diseases, but is perhaps best studied in the context of arthritis, a condition that can be effectively treated via blockade of IL-6 signaling (42). Synovial fibroblasts in inflamed joints are thought to be the major source of IL-6, which is likely produced in response to a variety of inflammatory factors including TNF, IL-1 $\beta$, LIF, and CDH11 $(47,53,63)$. IL-6 is necessary for pathology in preclinical models of antigen-induced and spontaneous arthritis, in which it orchestrates a variety of inflammatory processes including activation of CCL2 production by synovial fibroblasts, differentiation of autoinflammatory Th17 cells, and bone erosion via increased osteoclastogenesis (108-111). IL-6 has also been shown to promote CCL20 production by fibroblasts, which may further promote recruitment of inflammatory Th17 cells (112). IL-6 appears to promote arthritis primarily via trans signaling, likely because synovial fibroblasts and activated $\mathrm{CD} 4^{+} \mathrm{T}$ cells do not express sufficient IL-6R to respond to IL-6 alone $(108,109)$. Indeed, CCL2 production following IL- 6 stimulation of synovial fibroblasts requires the presence of soluble IL-6R, or a chimeric IL-6/IL-6R protein known as "hyper-IL-6" (108). IL-6 has also been shown to mediate fibrosis in the skin, lung, and heart (113116). Notably, in a phase 2 clinical trial of patients with systemic sclerosis, a disease characterized by skin fibrosis, treatment with actemra (tocilizumab; anti-IL6R) dramatically attenuated fibrotic behavior and transcriptional signatures in dermal fibroblasts, along with significant attenuation of disease severity (113).

\section{REGULATION OF INFLAMMATION AND HEMATOPOIESIS BY THE OSM-STROMAL CELL AXIS}

OSM is a pleiotropic cytokine with roles reported in a plethora of homeostatic and disease settings $(34,56,65)$. Unlike IL-6, OSM is not generally produced at significant levels by stromal cells, but is instead a product of various hematopoietic cell types, including monocytes, macrophages, dendritic cells, neutrophils, eosinophils, mast cells, and T cells $(34,56,65)$. OSM is further distinguished from IL- 6 by the cellular distribution of its specific receptors (OSMR and LIFR in humans; OSMR in mice), which are largely restricted to non-hematopoietic cell types, notably epithelial cells, fibroblasts, endothelial cells, adipocytes, and neurons $(34,56,65)$. OSM thus provides a means for leukocytes to deliver information to non-hematopoietic cells in inflamed or damaged tissues.

While little is known about the role of OSM in infectious disease or other host-defense settings, OSM can clearly influence hematopoietic homeostasis. OSM is necessary for the maintenance of granulocyte-macrophage, erythroid, megakaryocyte, and multipotential hematopoietic progenitor populations in the bone marrow, an effect that likely involves stimulation of bone marrow stromal cells by OSM (117-120). The ability of OSM to drive expression of CXCL12 (SDF1) in stromal cells may partly explain its effects on hematopoiesis $(119,121-123)$. However, aging studies have shown that OSMdeficient mice develop progressive hematological defects that include reduced numbers of circulating leukocytes, erythrocytes, and platelets, along with pronounced bone marrow adiposity. OSM was shown to suppress adipose differentiation of murine PDGFR $\alpha^{+} \mathrm{Sca}^{+}$mesenchymal stem cells, thereby preventing the development of "fatty" marrow and safeguarding the hematopoietic niche (120). Several additional studies have confirmed that OSM acts on stromal progenitors to suppress adipocyte differentiation in favor of osteoblast development (124-130), suggesting that OSM plays a fundamental role in regulating the bone marrow microenvironment. Notably, overexpression of OSM in bone marrow stromal cells promotes the development of lethal myeloproliferative neoplasms and bone marrow fibrosis in mice $(131,132)$.

Numerous studies have implicated OSM in the pathogenesis of inflammatory conditions, including arthritis, inflammatory bowel disease, psoriasis, and allergic airway inflammation. Intra-articular adenoviral delivery of OSM causes arthritislike pathology characterized by robust leukocyte infiltration, synovial hyperplasia, and erosion of bone and cartilage (133135). Consistent with these findings, antibody blockade of OSM can reduce pathology in the collagen-induced and pristanechallenge pre-clinical models of inflammatory arthritis (136). Synovial fibroblasts respond to OSM by producing a wide variety of inflammatory factors including cytokines (e.g., IL6), chemokines, (e.g., CCL2, CCL13, CXCL1), and leukocyte adhesion factors such as ICAM-1 (78, 82, 83, 134, 137-139). Furthermore, cytokine receptors such as IL1R1 (IL-1 receptor, type 1), gp130, and OSMR are induced by OSM, suggesting that OSM can sensitize synovial fibroblasts to additional cytokine stimulation. OSM can synergize with TNF and IL-1 $\beta$ to promote increased cytokine and chemokine expression, as well as high MMP (matrix metalloprotease) to TIMP1 (tissue inhibitor of metalloproteases) ratios to promote tissue damage. Remarkably, OSM alone drives high TIMP1 expression (134, 135, 138, 140, 141 ), and OSM only promotes net tissue degradation when acting in synergy with TNF, IL-1 $\beta$, or IL-17A, suggesting that its pathogenicity may depend on the presence of other inflammatory factors $(135,137,138,142)$.

Emerging data suggest an important role for OSM-stromal cell interactions in barrier tissues, such as skin and intestinal mucosa. Dermal fibroblasts express extracellular matrix components such as collagens and glycosaminoglycans in response to OSM, and display an interferon-like response featuring upregulation of the viral RNA sensors RIG-I and MDA5 (143-146). While sufficient to induce skin inflammation, OSM may not be required for psoriasis-like pathology, as it is dispensable in the aldara (imiquimod) challenge model of psoriasis $(55,147$, 148). OSM and OSMR are also overexpressed in the lesional skin of patients with atopic dermatitis, but whether OSM signaling is required for pathogenesis of this condition is unclear (147). A potentially non-redundant inflammatory role 
for OSM has been described for IBD, however. Unlike other barrier tissues such as the skin, normal epithelial cells do not express appreciable amounts of OSMR in either the mouse or human intestine (55). Intestinal fibroblasts, however, are highly sensitive to OSM and express a range of inflammatory factors in response to OSM stimulation, including IL-6, CCL2, CXCL10, and ICAM1. Like synovial fibroblasts, intestinal stromal cells show a synergistic inflammatory response to combined OSM and TNF treatment (55). Notably, genetic OSM deficiency or OSM blockade using an OSMR-gp130 fusion protein attenuates colitis in a dysbiosis-driven model of IBD that is refractory to anti-TNF therapy. Furthermore, OSM, OSMR, and stromal OSM response genes are highly predictive of resistance to anti-TNF therapy (e.g., infliximab and golimumab) in IBD patient cohorts, suggesting that high OSM expression drives an inflammatory axis that is mechanistically distinct from that of TNF (55). Intriguingly, OSM was not found to affect the early acute kinetics of colitis induction, but instead interfered with the resolution of inflammation, thereby contributing to disease chronicity and cumulative tissue damage. Experiments involving adenoviral overexpression of OSM in models of acute chemically induced colitis have yielded conflicting results, suggesting that the impact of OSM in these systems may be context dependent (149).

Consistent with data from studies of skin and joint inflammation, exogenous OSM promotes a robust inflammatory and tissue remodeling response in the lung (150-153), and blockade of OSM reduces disease severity in a mouse model of asthmatic airway inflammation (154). OSM stimulation of lung tissue induces a pronounced eosinophilia driven by OSMinduced expression of eotaxin (CCL11) in lung fibroblasts (152, 155). Unusually for an IL-6 family cytokine, OSM was shown to activate STAT6 in lung fibroblasts and activate CCL11 expression in synergy with IL-4 (155). OSM can also synergize with IL-4 to promote VCAM-1 expression by lung fibroblasts, which may promote increased eosinophil adhesion (156). Interestingly, the OSM-induced response in mouse lung tissue appears to differ between inbred strains. While intratracheal OSM promoted similar fibrotic changes in the lungs of $\mathrm{BALB} / \mathrm{c}$ and $\mathrm{C} 57 \mathrm{BL} / 6$ mice, only $\mathrm{C} 57 \mathrm{BL} / 6$ animals induced an inflammatory Th2 response (151). Straindependent effects are known to occur in other inflammatory disease settings such models of colitis, in which C57BL/6 mice often display differing disease susceptibility compared to animals from the BALB/c, 129.SvEv, or C3H/HeJBir backgrounds (157-165). This demonstrates the importance of considering strain-dependent effects when interpreting in vivo studies of OSM or other IL-6 family cytokines. Furthermore, such findings emphasize the challenges inherent in predicting the biology of humans (an outbred population) based on mouse model data. It is noteworthy that single nucleotide polymorphisms in the OSM and OSMR genetic loci are associated with risk of developing IBD (OSM and OSMR) and the IgA nephropathy form of glomerulonephritis (OSM), but the functional significance of these risk variants is not yet understood (166-168).

\section{LIF AND IL-11: STROMAL FACTORS WITH IMMUNOREGULATORY AND FIBROTIC PROPERTIES}

Unlike OSM, stromal cells appear to be important physiological sources of LIF and IL-11, both of which are produced in response to TGF $\beta$ stimulation $(62,66,68,169)$. While some studies have suggested pro-inflammatory roles for these cytokines $(63,170$, 171), substantial evidence suggests that they also exert important anti-inflammatory effects. Treatment with recombinant LIF was demonstrated over 20 years ago to protect mice from mortality and to reduce systemic TNF production in models of endotoxin-induced septic shock (172). Similar findings were later reported in LIF-deficient $\left(\mathrm{Lif}^{-/}{ }^{-}\right.$) mice. Compared to wild type mice, Lif $^{-/-}$animals had significantly greater mortality after endotoxin challenge, with dramatically increased levels of circulating TNF and IL-6 and reduced levels of IL-10, suggesting a potent anti-inflammatory effect (173). Treatment of mice and rats with recombinant IL-11 similarly reduced mortality, organ damage, and systemic cytokine production (TNF, IL$1 \beta$, and IFN- $\gamma$ ) in models of acute endotoxemia $(174,175)$. Recombinant IL-11 treatment likewise prevented T cell-driven liver injury in response to concanavalin-A, and protected mice from necrotizing pancreatitis following challenge with cerulein $(176,177)$.

Both LIF and IL-11 are reported to influence $\mathrm{CD}^{+}{ }^{+} \mathrm{T}$ cell differentiation, favoring Treg development and Th2 development, respectively. Whereas IL-6 suppresses Treg development and promotes Th17 differentiation in synergy with TGF $\beta$, LIF appears to have the opposite effect and can directly oppose the pro-Th17 activity of IL-6, possibly through induction of the negative regulatory factor SOCS3 $(178,179)$. Notably, LIF and IL-6 were identified as factors in human ovarian cancer ascites fluid that promoted differentiation of monocytes into anti-inflammatory macrophages with low IL-12 and high IL-10 production (100). In vitro culture models of human and mouse $\mathrm{CD}^{+} \mathrm{T}$ cells have demonstrated that IL- 11 represses Th1 polarization and promotes expression of IL-4, IL-5, and IL-10, which are associated with Th2 immunity $(180,181)$. IL-11 was also shown to inhibit IL-12 production from monocytes, which likely further attenuates Th1 development (180). IL-11 treatment was highly effective for preventing mortality in a mouse model of graft-vs.-host disease, in which it blocked expression of Th1-related cytokines (IL-12, IL-2, and IFN- $\gamma$ ), and induced production of IL-4 (182). Consistent with this Th2-promoting effect, IL-11 signaling is necessary for airway inflammation in mice challenged with inhaled OVA antigen or transgenic animals that overexpress IL-13 in the lung $(170,183)$. Following OVA challenge, $I l 11 \mathrm{ra}^{-/-}$mice showed dramatic reductions in lung-infiltrating Th2 cells, IL-13 expression, IgE production, and eosinophilia (170). Thus, while IL-11 can attenuate acute inflammation and Th1 responses, it may be pathogenic in conditions driven by Th2-polarized immunity.

Although LIF and IL-11 appear to have host-protective antiinflammatory properties in the context of acute inflammatory challenges, they may be deleterious in setting of chronic 
inflammation and tissue remodeling. Like IL-6, IL-11 can drive a STAT3-mediated regenerative program in epithelial cells, a function that promotes malignancy in cancers of the intestine, stomach, and mammary gland $(61,184-187)$. A recent study made the surprising observation that synovial fibroblasts express LIF in response to inflammatory cytokines such as TNF and IL17A, and autocrine LIF signaling drives STAT4, which synergizes with TNF/IL-17A-derived signals (NF- $\kappa$ B and C/EBP $\beta$ ) to promote potent expression of IL-6 (63). LIF may therefore be an important driver of pathogenic IL- 6 production in patients with rheumatoid arthritis. In cancer, LIF has been shown to activate cancer-associated fibroblasts to promote contractility, extracellular matrix remodeling, and cancer cell invasiveness (62, 66). Several studies have examined developmental abnormalities in transgenic mice that express either LIF or bovine OSM (a LIFR ligand in mice) downstream of the Lck promoter. These mice display a dramatic re-organization of lymph node structure, extrathymic T cell development, and myelosclerosis, suggesting that chronic overproduction of LIF in hematopoietic organs can have profound consequences on hematopoiesis (188194). Transgenic overexpression of IL-11 in mouse lung tissue provokes lymphocyte and myeloid infiltration and considerable subepithelial fibrosis (171). IL-11 was also shown to be mitogenic for lung fibroblasts isolated from either healthy donors or those with idiopathic pulmonary fibrosis (IPF). More recently, two studies that incorporated both human cell culture systems and pre-clinical mouse models highlighted the importance of IL-11 for fibrosis in the lung, heart, and kidney $(68,169)$. Intriguingly, IL-11 production in primary fibroblasts was shown to be induced by various pro-fibrotic stimuli (including PDGF, TGF $\beta$, IL-13, and OSM), and was critical for the adoption of a fibrogenic phenotype, suggesting that IL-11 mediates fibrosis in response to a wide variety of upstream stimuli $(68,169)$.

\section{STROMAL CONNECTIONS WITH IL-27}

As noted above, IL-27 differs structurally from other IL-6 family members, being a heterodimer comprised of IL-27p28 and EBI3 (19). IL-27 can be thought of as an IL-6 family member primarily because it depends on gp130 as a receptor component $(28,37$, 195). However, the structure of IL-27 is more comparable to that of IL-12 family members, all of which are similarly composed of heterodimers; IL-12 is comprised of IL-12p35 and IL-12p40, IL23 of IL-12p40 and IL-23p19, and IL-35 of IL-12p35 and EBI3 $(37,195)$. Compared to its siblings in the IL-6 family, relatively little is known about the physiological interactions between IL27 and stromal cells. In general, IL-27 has been studied in the context of communication between leukocyte populations, in which IL-27 can act in either an immunostimulatory or immunoregulatory capacity (37). For example, IL-27 synergizes with IL-12 to promote T-bet and IFN- $\gamma$ expression by CD4 ${ }^{+} \mathrm{T}$ cells, thus promoting Th1 polarization (19, 196-199). However, IL-27 can also drive differentiation of T-bet expressing regulatory T cells (200), an effect that is in direct contrast to IL-6, which suppresses Treg differentiation. In both mice and humans, IL-27 is also thought to be a key driver of the immunoregulatory $\operatorname{Tr} 1$ subset of $\mathrm{CD}^{+} \mathrm{T}$ cells, which specializes in IL-10 production to suppress inflammation (201-204). Because the well-studied hematopoietic effects of IL-27 are beyond the scope of this discussion, the reader is referred to recent reviews of the subject $(37,195)$.

IL-27 can directly influence stromal cells, although studies of this process are scarce. Like OSM, IL-27 can induce cytokine and chemokine production by fibroblasts from the synovium and lung, and does so in synergy with TNF or IL-1 $\beta(70,71)$. Factors induced in this manner include IL-6, CCL2, CXCL10, and ICAM-1 (70, 71). IL-27 has also been shown to enhance the sensitivity of pulmonary fibroblasts to lipopolysaccharide by promoting TLR4 expression (73). Finally, high circulating IL-27 concentrations are observed in patients with systemic sclerosis, and IL-27 stimulation of skin fibroblasts induced proliferation and collagen synthesis, implying a possible role for IL-27 in the fibrotic pathology of this disease (72). Thus, although IL-27 is best studied in the context of leukocyte-leukocyte interactions, it has the potential to regulate processes beyond those of the hematopoietic system through direct effects on stromal populations. A key challenge of future studies will be to determine whether IL-27 signaling in the stroma is functionally important in vivo.

\section{EFFECTS OF IL-6 FAMILY CYTOKINES ON OTHER NON-HEMATOPOIETIC CELL TYPES}

This review has dealt specifically with the impact of IL-6 family cytokines on a narrow group of mesenchymal cells that collectively include various phenotypes of fibroblasts. However, it should be noted that several other non-hematopoietic cell types can respond strongly to IL-6 family members and likely mediate at least some of their effects in vivo. Such populations include endothelial cells, adipocytes, muscle cells, chondrocytes, epithelial cells, and glial cells. Importantly, the functional effects of IL-6 family cytokines on fibroblasts overlap broadly with those reported for other cell types, suggesting a degree of functional conservation between non-hematopoietic populations. For example, both OSM and IL-6 are implicated as potent drivers of endothelial activation; in response to these cytokines, endothelial cells upregulate expression of chemokines and cytokines that include CCL2 and IL-6, as well as adhesion factors such as ICAM-1, VCAM-1, P-selectin, and E-selectin (79, 205-208). In this fashion, OSM and IL-6 are thought to promote leukocyte recruitment to inflamed tissues via stimulation of the endothelium. Because OSM and IL-6 exert similar effects on stromal cells, it is possible that these cytokines control the duration and intensity of inflammatory responses through coordinated action on multiple non-hematopoietic cell types. OSM similarly induces chemokine and cytokine production in chondrocytes, osteoblasts, and smooth muscle cells $(80,85,86,209,210)$.

The relative importance of these different cell populations for the execution of IL-6 family effects is poorly understood and probably context-dependent. For example, OSMR is highly 
expressed only by stromal cells in the intestinal mucosa, and it appears likely that these are the major mediators of OSM biology in this tissue (55). In contrast, OSMR is expressed broadly in many other tissues, making the identification of cell-type specific roles for OSM in these sites more challenging $(34,56,65,211)$. The ability of IL- 6 and IL-11 to signal via both classical and trans mechanisms adds further complexity, since potential responder cells require only the ubiquitously expressed gp130 to recognize the trans forms of these cytokines. As such, we know little about the cell type requirements for IL-6/IL-11 functions in vivo, particularly under conditions of inflammatory pathology $(18,41)$. Finally, the ability of IL- 6 family cytokines to modulate responses to other inflammatory mediators (e.g., TNF, IL-1 $\beta$, IL-17A, IL-4) means that their effects in vivo likely depend on the composition of the broader cytokine milieu, as well as the relative abundance of cell types capable of receiving signals from both IL-6 family members and their synergy partners. Beyond characterizing the "receivers" of IL-6 family cytokines, we are similarly limited in our understanding of their in vivo sources. For example, IL-6 has traditionally been thought of as a primarily leukocyte-derived factor, but this concept is challenged by our growing awareness of non-hematopoietic cell types as sources of this cytokine (as well as factors such as LIF and IL-11). There is thus a clear need for carefully constructed in vivo studies that abrogate expression of individual IL-6 family receptors or ligands in specific cell types. This is increasingly feasible due to the growing availability of transgenic mice with floxed alleles of IL- 6 family members and cell type-restricted Cre recombinase. Single-cell RNA-sequencing technology will also be a powerful tool to deconvolute the IL-6 family network in vivo.

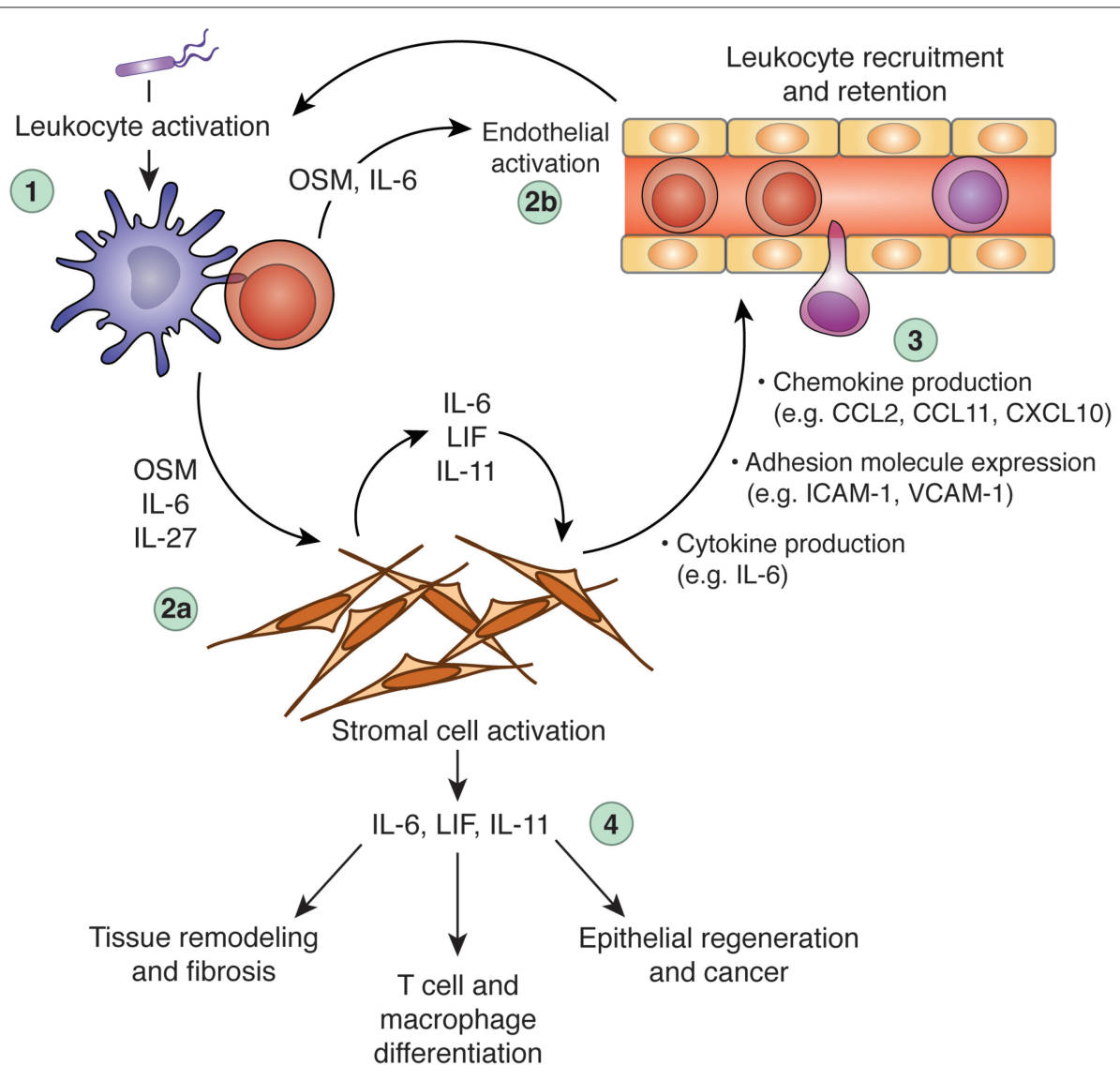

FIGURE 3 | Regulation of inflammation and tissue repair processes via cross-talk between leukocytes, the IL-6 family, and stromal cells. Dysregulation of IL-6 family cytokine expression can promote chronic inflammation, tissue remodeling, and fibrosis. In a hypothetical scenario of acute inflammation, an initial inflammatory insult (e.g., microbial sensing) triggers leukocyte activation and production of inflammatory mediators, including OSM, IL-6, and IL-27 (step 1). These cytokines can act alone or in synergy with other inflammatory mediators (e.g., TNF, IL-1 1 , IL-17A, etc.) to activate tissue-resident stromal cells (step 2a) and the local vasculature (step 2b). Stromal cells stimulated by IL-6 family members produce a wide array of additional inflammatory mediators and adhesion molecules, including IL-6, CCL2, CXCL10, and ICAM-1. These stroma-derived factors collectively promote leukocyte recruitment and retention (step 3), to potentiate the inflammatory response. Stromal cells stimulated by leukocyte-derived IL-6, OSM, or IL-27 (particularly in combination with other inflammatory cytokines) can produce IL-6 family cytokines in turn, including IL-6, LIF, and IL-11, which can further stimulate stromal cells through autocrine feedback or act on additional cell types to modulate leukocyte behavior (e.g., T cell polarization), tissue remodeling (e.g., matrix deposition), and tissue regeneration (step 4). When appropriately regulated, these processes constitute beneficial responses to tissue injury or infectious challenge. When dysregulated, however, these processes can become self-sustaining, leading to chronic inflammation and associated pathology. CCL, C-C motif chemokine ligand; CXCL10, C-X-C motif chemokine ligand 10; IL, interleukin; ICAM-1, intercellular adhesion molecule 1; LIF, leukemia inhibitor factor; OSM, oncostatin M; VCAM-1, vascular cell adhesion molecule 1. 


\section{TARGETING IL-6 FAMILY CYTOKINES IN THE CLINIC}

IL-6 is well established as a valuable clinical target, and antibodies that block either IL-6 (e.g., siltuximab) or IL6R (e.g., tocilizumab or sarilumab) are routinely used for treatment of inflammatory arthritis, juvenile idiopathic arthritis, multi-centric Castleman disease, cytokine release syndrome (commonly encountered in the setting of tumor immunotherapy), and giant cell arteritis (212-217). Despite these successes, clinical development of agents that target other members of the IL- 6 family has been modest [reviewed here (18)]. A humanized anti-OSM monoclonal antibody (GSK315234) was tested in a phase II trial of rheumatoid arthritis and found to be well tolerated, but without significant clinical activity (218). However, the limited efficacy of this antibody was ascribed to its relatively weak target affinity when compared to the native OSM receptor complex, and clinical studies with a next-generation high-affinity anti-OSM antibody are currently underway, focused this time on systemic sclerosis (ClinicalTrials.gov Identifier: NCT03041 025). Based on its immunoregulatory properties, a trial of recombinant IL-11 in rheumatoid arthritis was also conducted, but without success (219).

A concept that emerges from the previous sections of this review is the substantial degree of functional similarity and crossregulation between IL-6 family members. As such, targeting a single member of the IL- 6 family for treatment of aetiologically complex diseases may be insufficient to fully engage the biology of interest. For example, although many patients with arthritis benefit from anti-IL6R therapy, this benefit is usually restricted to an incomplete decrease in disease activity, suggesting that other inflammatory pathways are in play $(213,216)$. Indeed, virtually all members of the IL-6 family (IL-6, OSM, LIF, IL11, and IL-27) have been implicated as drivers of fibrosis. This raises the possibility that combinatorial blockade of two or more factors may be necessary to effectively neutralize IL6 family biology in a given disease setting. Although clinical experience with JAK inhibitors (which block signaling from broad spectra of cytokines) demonstrates that simultaneous targeting of multiple cytokine pathways can be achieved (220), the efficacy of targeting multiple IL-6 family members would nevertheless require careful balancing against potential

\section{REFERENCES}

1. Owens BMJ. Inflammation, innate immunity, and the intestinal stromal cell niche: opportunities and challenges. Front Immunol. (2015) 6:319. doi: 10.3389/fimmu.2015.0 0319

2. Buechler MB, Turley SJ. A short field guide to fibroblast function in immunity. Semin Immunol. (2018) 35:4858. doi: 10.1016/j.smim.2017.11.001

3. Farr AG, Berry ML, Kim A, Nelson AJ, Welch MP, Aruffo A. Characterization and cloning of a novel glycoprotein expressed by stromal cells in Tdependent areas of peripheral lymphoid tissues. J Exp Med. (1992) 176:147782. doi: 10.1084/jem.176.5.1477 unexpected toxicities, particularly in the case of antibodies with slow rates of systemic clearance. The probability of success with such approaches will likely be increased by a combination of biomarker-guided patient stratification [e.g., OSM expression in IBD (55)] and the careful selection of combination candidates based on gene expression patterns in human tissues and mechanistic insights derived from carefully conducted pre-clinical studies.

\section{CONCLUDING REMARKS}

Increasing evidence indicates that stromal cells are integral to the biology of IL- 6 family cytokines, both in healthy and pathological scenarios. Stromal cells both produce and sense IL-6 family cytokines, and can therefore not only respond to leukocytederived signals (e.g., OSM or IL-27), but also instruct leukocyte behavior (e.g., by producing IL-6, IL-11, or LIF) to influence the course of immunological processes (Figure 3). Although it is clear that IL-6 family cytokines play diverse roles in vivo, it is rare to identify specific cell types that are responsible for either cytokine production or cytokine responses. As such, although it is apparent that interactions between IL-6 family cytokines and stromal cells occur, whether these interactions are necessary in vivo is generally unclear. For example, while stromal cells appear to be important sources of IL-6 in models of inflammatory disease, whether they are indispensable sources of IL- 6 has not been formally demonstrated. Similarly, while it is likely that stromal cells are key mediators of OSM biology in the intestine, the possibility that other mesenchymal cell types (or a hitherto unknown hematopoietic cell population) are involved cannot be ruled out. Greater use of genetic tools in animal studies, such as cell-type specific deletion of specific cytokine or cytokine receptor genes, is required to draw a more accurate roadmap of the functional connections between IL- 6 family cytokines, individual cell types, and distinct biological processes. Rendering this map in greater detail will be critical for translating our knowledge of IL-6 family biology into clinical benefit.

\section{AUTHOR CONTRIBUTIONS}

NW conceived and wrote the manuscript, and prepared figures for this review.
4. Fletcher AL, Acton SE, Knoblich K. Lymph node fibroblastic reticular cells in health and disease. Nature. (2015) 15:350-61. doi: 10.1038/nri3846

5. Astarita JL, Acton SE, Turley SJ. Podoplanin: emerging functions in development, the immune system, and cancer. Front Immunol. (2012) 3:283. doi: 10.3389/fimmu.2012.00283

6. Neyt K, Perros F, GeurtsvanKessel CH, Hammad H, Lambrecht BN. Tertiary lymphoid organs in infection and autoimmunity. Trends Immunol. (2012) 33:297-305. doi: 10.1016/j.it.2012.04.006

7. Buckley CD, Barone F, Nayar S, Bénézech C, Caamaño J. Stromal cells in chronic inflammation and tertiary lymphoid organ formation. Annu Rev Immunol. (2015) 33:715-45. doi: 10.1146/annurev-immunol-032713-120252

8. Owens BMJ, Simmons A. Intestinal stromal cells in mucosal immunity and homeostasis. Mucosal Immunol. (2013) 6:224-34. doi: 10.1038/mi.2012.125 
9. Dakin SG, Coles M, Sherlock JP, Powrie F, Carr AJ, Buckley CD. Pathogenic stromal cells as therapeutic targets in joint inflammation. Nat Rev Rheumatol. (2018) 14:714-26. doi: 10.1038/s41584-018-0112-7

10. Khan O, Headley M, Gerard A, Wei W, Liu L, Krummel MF. Regulation of $\mathrm{T}$ cell priming by lymphoid stroma. PLoS ONE. (2011) 6:e26138. doi: 10.1371/journal.pone.0026138

11. Siegert S, Huang H-Y, Yang C-Y, Scarpellino L, Carrie L, Essex $\mathrm{S}$, et al. Fibroblastic reticular cells from lymph nodes attenuate $\mathrm{T}$ cell expansion by producing nitric oxide. PLoS ONE. (2011) 6:e27618. doi: 10.1371/journal.pone.0027618

12. Lukacs-Kornek V, Malhotra D, Fletcher AL, Acton SE, Elpek KG, Tayalia P, et al. Regulated release of nitric oxide by nonhematopoietic stroma controls expansion of the activated T cell pool in lymph nodes. Nat Immunol. (2011) 12:1096-104. doi: 10.1038/ni.2112

13. Tykocinski L-O, Lauffer AM, Bohnen A, Kaul N-C, Krienke S, Tretter T, et al. Synovial fibroblasts selectively suppress Th1 cell responses through IDO1-mediated tryptophan catabolism. J Immunol. (2017) 198:310917. doi: 10.4049/jimmunol.1600600

14. Haniffa MA, Wang X-N, Holtick U, Rae M, Isaacs JD, Dickinson AM, et al. Adult human fibroblasts are potent immunoregulatory cells and functionally equivalent to mesenchymal stem cells. J Immunol. (2007) 179:1595-604. doi: 10.4049/jimmunol.179.3.1595

15. Wynn TA. Integrating mechanisms of pulmonary fibrosis. J Exp Med. (2011) 208:1339-50. doi: 10.1084/jem.20110551

16. Piersma B, Bank RA, Boersema M. Signaling in fibrosis: TGF- $\beta$, WNT, and YAP/TAZ converge. Front Med. (2015) 2:59. doi: 10.3389/fmed.2015.00059

17. Garbers C, Hermanns HM, Schaper F, Müller-Newen G, Grötzinger J, Rose-John S, et al. Plasticity and cross-talk of interleukin 6-type cytokines. Cytokine Growth Factor Rev. (2012) 23:85-97. doi: 10.1016/j.cytogfr.2012.04.001

18. Jones SA, Jenkins BJ. Recent insights into targeting the IL-6 cytokine family in inflammatory diseases and cancer. Nat Rev Immunol. (2018) 18:77389. doi: 10.1038/s41577-018-0066-7

19. Pflanz S, Timans JC, Cheung J, Rosales R, Kanzler H, Gilbert J, et al. IL-27, a heterodimeric cytokine composed of EBI3 and p28 protein, induces proliferation of naive CD4+ T cells. Immunity. (2002) 16:77990. doi: 10.1016/S1074-7613(02)00324-2

20. Boulanger MJ, Chow D-C, Brevnova EE, Garcia KC. Hexameric structure and assembly of the interleukin-6/IL-6 alpha-receptor/gp130 complex. Science. (2003) 300:2101-4. doi: 10.1126/science.1083901

21. Barton VA, Hall MA, Hudson KR, Heath JK. Interleukin-11 signals through the formation of a hexameric receptor complex. J Biol Chem. (2000) 275:36197-203. doi: 10.1074/jbc.M004648200

22. Matadeen R, Hon W-C, Heath JK, Jones EY, Fuller S. The dynamics of signal triggering in a gp130-receptor complex. Structure. (2007) 15:4418. doi: $10.1016 /$ j.str.2007.02.006

23. Liu J, Modrell B, Aruffo A, Scharnowske S, Shoyab M. Interactions between oncostatin M and the IL-6 signal transducer, gp130. Cytokine. (1994) 6:2728. doi: 10.1016/1043-4666(94)90023-X

24. Gearing DP, Comeau MR, Friend DJ, Gimpel SD, Thut CJ, McGourty J, et al. The IL-6 signal transducer, gp130: an oncostatin M receptor and affinity converter for the LIF receptor. Science. (1992) 255:14347. doi: $10.1126 /$ science. 1542794

25. Mosley B, De Imus C, Friend D, Boiani N, Thoma B, Park LS, et al. Dual oncostatin M (OSM) receptors. Cloning and characterization of an alternative signaling subunit conferring OSM-specific receptor activation. J Biol Chem. (1996) 271:32635-43. doi: 10.1074/jbc.271.51.32635

26. Skiniotis G, Lupardus PJ, Martick M, Walz T, Garcia KC. Structural organization of a full-length gp130/LIF-R cytokine receptor transmembrane complex. Mol Cell. (2008) 31:737-48. doi: 10.1016/j.molcel.2008.08.011

27. Gearing DP, Thut CJ, VandeBos T, Gimpel SD, Delaney PB, King J, et al. Leukemia inhibitory factor receptor is structurally related to the IL-6 signal transducer, gp130. EMBO J. (1991) 10:2839-48. doi: 10.1002/j.1460-2075.1991.tb07833.x

28. Pflanz S, Hibbert L, Mattson J, Rosales R, Vaisberg E, Bazan JF, et al. WSX-1 and glycoprotein 130 constitute a signal-transducing receptor for IL-27. J Immunol. (2004) 172:2225-31. doi: 10.4049/jimmunol.172.4. 2225
29. Davis S, Aldrich TH, Stahl N, Pan L, Taga T, Kishimoto T, et al. LIFR beta and gp130 as heterodimerizing signal transducers of the tripartite CNTF receptor. Science. (1993) 260:1805-8. doi: 10.1126/science.8390097

30. Davis S, Aldrich TH, Valenzuela DM, Wong VV, Furth ME, Squinto SP, et al. The receptor for ciliary neurotrophic factor. Science. (1991) 253:5963. doi: $10.1126 /$ science. 1648265

31. Sims NA. Cardiotrophin-like cytokine factor 1 (CLCF1) and neuropoietin (NP) signalling and their roles in development, adulthood, cancer and degenerative disorders. Cytokine Growth Factor Rev. (2015) 26:51722. doi: 10.1016/j.cytogfr.2015.07.014

32. Lindberg RA, Juan TS, Welcher AA, Sun Y, Cupples R, Guthrie B, et al. Cloning and characterization of a specific receptor for mouse oncostatin $\mathrm{M}$. Mol Cell Biol. (1998) 18:3357-67. doi: 10.1128/MCB.18.6.3357

33. Drechsler J, Grötzinger J, Hermanns HM. Characterization of the rat oncostatin $M$ receptor complex which resembles the human, but differs from the murine cytokine receptor. PLoS ONE. (2012) 7:e43155. doi: 10.1371/journal.pone.0043155

34. Hermanns HM. Oncostatin M and interleukin-31: Cytokines, receptors, signal transduction and physiology. Cytokine Growth Factor Rev. (2015) 26:545-58. doi: 10.1016/j.cytogfr.2015.07.006

35. Heinrich PC, Behrmann I, Haan S, Hermanns HM, Müller-Newen G, Schaper F. Principles of interleukin (IL)-6-type cytokine signalling and its regulation. Biochem J. (2003) 374:1-20. doi: 10.1042/bj20030407

36. Hermanns HM, Radtke S, Schaper F, Heinrich PC, Behrmann I. Nonredundant signal transduction of interleukin-6-type cytokines. J Biol Chem. (2000) 275:40742-8. doi: 10.1074/jbc.M005408200

37. Jones GW, Hill DG, Cardus A, Jones SA. IL-27: a double agent in the IL-6 family. Clin Exp Immunol. (2018) 193:37-46. doi: 10.1111/cei.13116

38. Rose-John S, Heinrich PC. Soluble receptors for cytokines and growth factors: generation and biological function. Biochem J. (1994) 300(Pt 2):28190. doi: 10.1042/bj3000281

39. Peters M, Jacobs S, Ehlers M, Vollmer P, Müllberg J, Wolf E, et al. The function of the soluble interleukin 6 (IL-6) receptor in vivo: sensitization of human soluble IL-6 receptor transgenic mice towards IL-6 and prolongation of the plasma half-life of IL-6. J Exp Med. (1996) 183:1399406. doi: $10.1084 /$ jem. 183.4 .1399

40. Jones SA, Horiuchi S, Topley N, Yamamoto N, Fuller GM. The soluble interleukin 6 receptor: mechanisms of production and implications in disease. FASEB J. (2001) 15:43-58. doi: 10.1096/fj.99-1003rev

41. Hunter CA, Jones SA. IL-6 as a keystone cytokine in health and disease. Nat Immunol. (2015) 16:448-57. doi: 10.1038/ni.3153

42. Garbers C, Heink S, Korn T, Rose-John S. Interleukin-6: designing specific therapeutics for a complex cytokine. Nat Rev Drug Discov. (2018) 17:395412. doi: $10.1038 / \mathrm{nrd} .2018 .45$

43. Georganas C, Liu H, Perlman H, Hoffmann A, Thimmapaya B, Pope RM. Regulation of IL-6 and IL-8 expression in rheumatoid arthritis synovial fibroblasts: the dominant role for NF-kappa B but not C/EBP beta or c-Jun. $J$ Immunol. (2000) 165:7199-206. doi: 10.4049/jimmunol.165.12.7199

44. Hosokawa I, Hosokawa Y, Ozaki K, Yumoto H, Nakae H, Matsuo T. Proinflammatory effects of muramyldipeptide on human gingival fibroblasts. J Periodont Res. (2010) 45:193-9. doi: 10.1111/j.1600-0765.2009.01217.x

45. Kyburz D, Rethage J, Seibl R, Lauener R, Gay RE, Carson DA, et al. Bacterial peptidoglycans but not $\mathrm{CpG}$ oligodeoxynucleotides activate synovial fibroblasts by toll-like receptor signaling. Arthritis Rheum. (2003) 48:642-50. doi: 10.1002/art.10848

46. Ospelt C, Brentano F, Jüngel A, Rengel Y, Kolling C, Michel $\mathrm{BA}$, et al. Expression, regulation, and signaling of the patternrecognition receptor nucleotide-binding oligomerization domain 2 in rheumatoid arthritis synovial fibroblasts. Arthritis Rheum. (2009) 60:355-63. doi: 10.1002/art.24226

47. Fossiez F, Djossou O, Chomarat P, Flores-Romo L, Ait-Yahia S, Maat $\mathrm{C}$, et al. $\mathrm{T}$ cell interleukin-17 induces stromal cells to produce proinflammatory and hematopoietic cytokines. J Exp Med. (1996) 183:2593-603. doi: 10.1084/jem.183.6.2593

48. Hata K, Andoh A, Shimada M, Fujino S, Bamba S, Araki Y, et al. IL17 stimulates inflammatory responses via NF-kappaB and MAP kinase pathways in human colonic myofibroblasts. Am J Physiol Gastrointest Liver Physiol. (2002) 282:G1035-44. doi: 10.1152/ajpgi.00494.2001 
49. Andoh A, Hata K, Araki Y, Fujiyama Y, Bamba T. Interleukin (IL)-4 and IL17 synergistically stimulate IL-6 secretion in human colonic myofibroblasts. Int J Mol Med. (2002) 10:631-4. doi: 10.3892/ijmm.10.5.631

50. Shimada M, Andoh A, Hata K, Tasaki K, Araki Y, Fujiyama Y, et al. IL-6 secretion by human pancreatic periacinar myofibroblasts in response to inflammatory mediators. J Immunol. (2002) 168:8618. doi: 10.4049/jimmunol.168.2.861

51. Katz Y, Nadiv O, Beer Y. Interleukin-17 enhances tumor necrosis factor $\alpha$-induced synthesis of interleukins 1,6 , and 8 in skin and synovial fibroblasts: a possible role as a "fine-tuning cytokine" in inflammation processes. Arthritis Rheum. (2001) 44:217684. doi: 10.1002/1529-0131(200109)44:9<2176::AID-ART371>3.0.CO;2-4

52. Parsonage G, Falciani F, Burman A, Filer A, Ross E, Bofill M, et al. Global gene expression profiles in fibroblasts from synovial, skin and lymphoid tissue reveals distinct cytokine and chemokine expression patterns. Thrombosis Haemostasis. (2003) 90:688-97. doi: 10.1160/TH03-04-0208

53. Chang SK, Noss EH, Chen M, Gu Z, Townsend K, Grenha R, et al. Cadherin-11 regulates fibroblast inflammation. Proc Natl Acad Sci USA. (2011) 108:8402-7. doi: 10.1073/pnas.1019437108

54. Dufour AM, Alvarez M, Russo B, Chizzolini C. Interleukin-6 and typeI collagen production by systemic sclerosis fibroblasts are differentially regulated by interleukin-17A in the presence of transforming growth factorbeta 1. Front Immunol. (2018) 9:1865. doi: 10.3389/fimmu.2018.01865

55. West NR, Hegazy AN, Owens BMJ, Bullers SJ, Linggi B, Buonocore S, et al. Oncostatin $\mathrm{M}$ drives intestinal inflammation and predicts response to tumor necrosis factor-neutralizing therapy in patients with inflammatory bowel disease. Nature. (2017) 23:579-89. doi: 10.1038/nm.4307

56. West NR, Owens BMJ, Hegazy AN. The oncostatin M-stromal cell axis in health and disease. Scand J Immunol. (2018) 88:e1269418. doi: $10.1111 /$ sji.12694

57. Eickelberg O, Pansky A, Mussmann R, Bihl M, Tamm M, Hildebrand P, et al. Transforming growth factor-betal induces interleukin- 6 expression via activating protein-1 consisting of JunD homodimers in primary human lung fibroblasts. J Biol Chem. (1999) 274:12933-8. doi: 10.1074/jbc.274.18.12933

58. Coppé J-P, Desprez P-Y, Krtolica A, Campisi J. The senescence-associated secretory phenotype: the dark side of tumor suppression. Annu Rev Pathol. (2010) 5:99-118. doi: 10.1146/annurev-pathol-121808-102144

59. Valencia T, Kim JY, Abu-Baker S, Moscat-Pardos J, Ahn CS, Reina-Campos $\mathrm{M}$, et al. Metabolic reprogramming of stromal fibroblasts through p62mTORC1 signaling promotes inflammation and tumorigenesis. Cancer Cell. (2014) 26:121-35. doi: 10.1016/j.ccr.2014.05.004

60. Lorgeot V, Rougier F, Fixe P, Cornu E, Praloran V, Denizot Y. Spontaneous and inducible production of leukaemia inhibitory factor by human bone marrow stromal cells. Cytokine. (1997) 9:754-8. doi: 10.1006/ cyto.1997.0225

61. Calon A, Espinet E, Palomo-Ponce S, Tauriello DVF, Iglesias M, Céspedes MV, et al. Dependency of colorectal cancer on a TGF- $\beta$-driven program in stromal cells for metastasis initiation. Cancer Cell. (2012) 22:57184. doi: 10.1016/j.ccr.2012.08.013

62. Albrengues J, Bourget I, Pons C, Butet V, Hofman P, Tartare-Deckert S, et al. LIF mediates proinvasive activation of stromal fibroblasts in cancer. Cell Rep. (2014) 7:1664-78. doi: 10.1016/j.celrep.2014.04.036

63. Nguyen HN, Noss EH, Mizoguchi F, Huppertz C, Wei KS, Watts GFM, et al. Autocrine loop involving IL-6 family member LIF, LIF receptor, and STAT4 drives sustained fibroblast production of inflammatory mediators. Immunity. (2017) 46:220-32. doi: 10.1016/j.immuni.2017.01.004

64. Souza PPC, Palmqvist P, Lundberg P, Lundgren I, Hänström L, Souza JAC, et al. Interleukin-4 and interleukin-13 inhibit the expression of leukemia inhibitory factor and interleukin-11 in fibroblasts. Mol Immunol. (2012) 49:601-10. doi: 10.1016/j.molimm.2011.10.009

65. Richards $\mathrm{CD}$. The enigmatic cytokine oncostatin $\mathrm{M}$ and roles in disease. ISRN Inflammation. (2013) 2013:1-23. doi: 10.1155/2013/512103

66. Albrengues J, Bertero T, Grasset E, Bonan S, Maiel M, Bourget I, et al. Epigenetic switch drives the conversion of fibroblasts into proinvasive cancer-associated fibroblasts. Nat Commun. (2015) 6:10204. doi: $10.1038 /$ ncomms 10204

67. Elshabrawy HA, Volin MV, Essani AB, Chen Z, McInnes IB, Van Raemdonck $\mathrm{K}$, et al. IL-11 facilitates a novel connection between
RA joint fibroblasts and endothelial cells. Angiogenesis. (2018) 21:21528. doi: 10.1007/s10456-017-9589-y

68. Schafer S, Viswanathan S, Widjaja AA, Lim W-W, Moreno-Moral A, DeLaughter DM, et al. IL-11 is a crucial determinant of cardiovascular fibrosis. Nature. (2017) 552:110-5. doi: 10.1038/nature24676

69. Moodley YP, Scaffidi AK, Misso NL, Keerthisingam C, McAnulty RJ, Laurent GJ, et al. Fibroblasts isolated from normal lungs and those with idiopathic pulmonary fibrosis differ in interleukin-6/gp130mediated cell signaling and proliferation. Am J Pathol. (2003) 163:34554. doi: 10.1016/S0002-9440(10)63658-9

70. Wong CK, Chen DP, Tam LS, Li EK, Yin YB, Lam CWK. Effects of inflammatory cytokine IL-27 on the activation of fibroblastlike synoviocytes in rheumatoid arthritis. Arthritis Res Ther. (2010) 12:R129. doi: 10.1186/ar3067

71. Dong S, Zhang X, He Y, Xu F, Li D, Xu W, et al. Synergy of IL-27 and TNF- $\alpha$ in regulating CXCL10 expression in lung fibroblasts. Am J Respir Cell Mol Biol. (2013) 48:518-30. doi: 10.1165/rcmb.2012-0340OC

72. Yoshizaki A, Yanaba K, Iwata Y, Komura K, Ogawa A, Muroi E, et al. Elevated serum interleukin-27 levels in patients with systemic sclerosis: association with T cell, B cell and fibroblast activation. Ann Rheum Dis. (2011) 70:194-200. doi: 10.1136/ard.2009.121053

73. Su Y, Yao H, Wang H, Xu F, Li D, Li D, et al. IL-27 enhances innate immunity of human pulmonary fibroblasts and epithelial cells through upregulation of TLR4 expression. Am J Physiol Lung Cell Mol Physiol. (2016) 310:L13341. doi: 10.1152/ajplung.00307.2015

74. Wong C-K, Leung KM-L, Qiu H-N, Chow JY-S, Choi AOK, Lam CW-K. Activation of eosinophils interacting with dermal fibroblasts by pruritogenic cytokine IL-31 and alarmin IL-33: implications in atopic dermatitis. PLoS ONE. (2012) 7:e29815. doi: 10.1371/journal.pone.0029815

75. Jawa RS, Chattopadhyay S, Tracy E, Wang Y, Huntoon K, Dayton MT, et al. Regulated expression of the IL-31 receptor in bronchial and alveolar epithelial cells, pulmonary fibroblasts, and pulmonary macrophages. $J$ Interferon Cytokine Res. (2008) 28:207-19. doi: 10.1089/jir.2007.0057

76. Chou DB, Sworder B, Bouladoux N, Roy CN, Uchida AM, Grigg M, et al. Stromal-derived IL-6 alters the balance of myeloerythroid progenitors during Toxoplasma gondii infection. J Leukocyte Biol. (2012) 92:12331. doi: $10.1189 / \mathrm{jlb} .1011527$

77. Lagneaux L, Delforge A, Snoeck R, Bosmans E, Moreau JF, Taupin JL, et al. Human cytomegalovirus increases constitutive production of interleukin6 and leukemia inhibitory factor by bone marrow stromal cells. Blood. (1996) 87:59-66.

78. Richards CD, Langdon C, Botelho F, Brown TJ, Agro A. Oncostatin $\mathrm{M}$ inhibits IL-1-induced expression of IL-8 and granulocyte-macrophage colony-stimulating factor by synovial and lung fibroblasts. J Immunol. (1996) $156: 343-9$.

79. Modur V, Feldhaus MJ, Weyrich AS, Jicha DL, Prescott SM, Zimmerman GA, et al. Oncostatin $\mathrm{M}$ is a proinflammatory mediator. In vivo effects correlate with endothelial cell expression of inflammatory cytokines and adhesion molecules. J Clin Invest. (1997) 100:158-68. doi: 10.1172/JCI119508

80. Schnittker D, Kwofie K, Ashkar A, Trigatti B, Richards CD. Oncostatin M and TLR-4 ligand synergize to induce MCP-1, IL-6, and VEGF in human aortic adventitial fibroblasts and smooth muscle cells. Mediat Inflamm. (2013) 2013:1-14. doi: 10.1155/2013/317503

81. Ruprecht K, Kuhlmann T, Seif F, Hummel V, Kruse N, Brück W, et al. Effects of oncostatin $\mathrm{M}$ on human cerebral endothelial cells and expression in inflammatory brain lesions. J Neuropathol Exp Neurol. (2001) 60:108798. doi: $10.1093 /$ jnen $/ 60.11 .1087$

82. Le Goff B, Singbrant S, Tonkin BA, Martin TJ, Romas E, Sims $\mathrm{NA}$, et al. Oncostatin $\mathrm{M}$ acting via OSMR, augments the actions of IL-1 and TNF in synovial fibroblasts. Cytokine. (2014) 68:1019. doi: 10.1016/j.cyto.2014.04.001

83. Migita K, Komori A, Torigoshi T, Maeda Y, Izumi Y, Jiuchi Y, et al. CP690,550 inhibits oncostatin M-induced JAK/STAT signaling pathway in rheumatoid synoviocytes. Arthritis Res Ther. (2011) 13:R72. doi: 10.1186/ar3333

84. Hurst SM, McLoughlin RM, Monslow J, Owens S, Morgan L, Fuller GM, et al. Secretion of oncostatin M by infiltrating neutrophils: regulation of IL6 and chemokine expression in human mesothelial cells. J Immunol. (2002) 169:5244-51. doi: 10.4049/jimmunol.169.9.5244 
85. Faffe DS, Flynt L, Mellema M, Whitehead TR, Bourgeois K, Panettieri RA, et al. Oncostatin M causes VEGF release from human airway smooth muscle: synergy with IL-1beta. AJP Lung Cell Mol Physiol. (2005) 288:L10408. doi: 10.1152/ajplung.00333.2004

86. Kwofie K, Scott M, Rodrigues R, Guerette J, Radford K, Nair P, et al. Regulation of IL-17A responses in human airway smooth muscle cells by Oncostatin M. Respir Res. (2015) 16:14. doi: 10.1186/s12931-014-0164-4

87. Kinchen J, Chen HH, Parikh K, Antanaviciute A, Jagielowicz M, Fawkner-Corbett D, et al. Structural remodeling of the human colonic mesenchyme in inflammatory bowel disease. Cell. (2018) 175:372386.e17. doi: 10.1016/j.cell.2018.08.067

88. Noss EH, Nguyen HN, Chang SK, Watts GFM, Brenner MB. Genetic polymorphism directs IL-6 expression in fibroblasts but not selected other cell types. Proc Natl Acad Sci USA. (2015) 112:14948-53. doi: 10.1073/pnas.1520861112

89. Huang H-Y, Rivas-Caicedo A, Renevey F, Cannelle H, Peranzoni E, Scarpellino L, et al. Identification of a new subset of lymph node stromal cells involved in regulating plasma cell homeostasis. Proc Natl Acad Sci USA. (2018) 115:E6826-35. doi: 10.1073/pnas.1712628115

90. Zhang Y, Tech L, George LA, Acs A, Durrett RE, Hess H, et al. Plasma cell output from germinal centers is regulated by signals from Tfh and stromal cells. J Exp Med. (2018) 215:1227-43. doi: 10.1084/jem.20160832

91. Vinuesa CG, Linterman MA, Yu D, MacLennan ICM. Follicular helper T cells. Annu Rev Immunol. (2016) 34:33568. doi: 10.1146/annurev-immunol-041015-055605

92. Dienz O, Eaton SM, Bond JP, Neveu W, Moquin D, Noubade R, et al. The induction of antibody production by IL-6 is indirectly mediated by IL-21 produced by CD4+ T cells. J Exp Med. (2009) 206:6978. doi: 10.1084/jem.20081571

93. Ise W, Kurosaki T. Plasma cell differentiation during the germinal center reaction. Immunol Rev. (2019) 288:64-74. doi: 10.1111/imr.12751

94. Wu H, Deng Y, Zhao M, Zhang J, Zheng M, Chen G, et al. Molecular control of follicular helper T cell development and differentiation. Front Immunol. (2018) 9:2470. doi: 10.3389/fimmu.2018.02470

95. Heng TSP, Painter MW, Immunological Genome Project Consortium. The immunological genome project: networks of gene expression in immune cells. Nat Immunol. (2008) 9:1091-4. doi: 10.1038/ni1008-1091

96. Hurst SM, Wilkinson TS, McLoughlin RM, Jones S, Horiuchi S, Yamamoto $\mathrm{N}$, et al. Il-6 and its soluble receptor orchestrate a temporal switch in the pattern of leukocyte recruitment seen during acute inflammation. Immunity. (2001) 14:705-14. doi: 10.1016/S1074-7613(01)00151-0

97. Zhang $\mathrm{H}, \mathrm{Hu} \mathrm{H}$, Greeley N, Jin J, Matthews AJ, Ohashi E, et al. STAT3 restrains RANK- and TLR4-mediated signalling by suppressing expression of the E2 ubiquitin-conjugating enzyme Ubc13. Nat Commun. (2014) 5:5798. doi: $10.1038 /$ ncomms6798

98. Chomarat P, Banchereau J, Davoust J, Palucka AK. IL-6 switches the differentiation of monocytes from dendritic cells to macrophages. Nat Immunol. (2000) 1:510-4. doi: 10.1038/82763

99. Chomarat P, Dantin C, Bennett L, Banchereau J, Palucka AK. TNF skews monocyte differentiation from macrophages to dendritic cells. J Immunol. (2003) 171:2262-9. doi: 10.4049/jimmunol.171.5 .2262

100. Duluc D, Delneste Y, Tan F, Moles M-P, Grimaud L, Lenoir J, et al. Tumor-associated leukemia inhibitory factor and IL-6 skew monocyte differentiation into tumor-associated macrophage-like cells. Blood. (2007) 110:4319-30. doi: 10.1182/blood-2007-02-072587

101. Bleier JI, Pillarisetty VG, Shah AB, DeMatteo RP. Increased and long-term generation of dendritic cells with reduced function from IL-6-deficient bone marrow. J Immunol. (2004) 172:7408-16. doi: 10.4049/jimmunol.172.12.7408

102. Mauer J, Chaurasia B, Goldau J, Vogt MC, Ruud J, Nguyen KD, et al. Signaling by IL-6 promotes alternative activation of macrophages to limit endotoxemia and obesity-associated resistance to insulin. Nat Immunol. (2014) 15:423-30. doi: 10.1038/ni.2865

103. Silver JS, Stumhofer JS, Passos S, Ernst M, Hunter CA. IL-6 mediates the susceptibility of glycoprotein 130 hypermorphs to Toxoplasma gondii. J Immunol. (2011) 187:350-60. doi: 10.4049/jimmunol.10 04144
104. Beaman MH, Hunter CA, Remington JS. Enhancement of intracellular replication of Toxoplasma gondii by IL-6. Interactions with IFN-gamma and TNF-alpha. J Immunol. (1994) 153:4583-7.

105. Nagabhushanam V, Solache A, Ting L-M, Escaron CJ, Zhang JY, Ernst JD. Innate inhibition of adaptive immunity: Mycobacterium tuberculosisinduced IL-6 inhibits macrophage responses to IFN-gamma. J Immunol. (2003) 171:4750-7. doi: 10.4049/jimmunol.171.9.4750

106. Grivennikov S, Karin E, Terzic J, Mucida D, Yu G-Y, Vallabhapurapu S, et al. IL-6 and Stat3 are required for survival of intestinal epithelial cells and development of colitis-associated cancer. Cancer Cell. (2009) 15:10313. doi: 10.1016/j.ccr.2009.01.001

107. Barton BE, Shortall J, Jackson JV. Interleukins 6 and 11 protect mice from mortality in a staphylococcal enterotoxin-induced toxic shock model. Infect Immun. (1996) 64:714-8.

108. Nowell MA, Richards PJ, Horiuchi S, Yamamoto N, Rose-John S, Topley N, et al. Soluble IL-6 receptor governs IL-6 activity in experimental arthritis: blockade of arthritis severity by soluble glycoprotein 130. J Immunol. (2003) 171:3202-9. doi: 10.4049/jimmunol.171.6.3202

109. Nowell MA, Williams AS, Carty SA, Scheller J, Hayes AJ, Jones GW, et al. Therapeutic targeting of IL-6 trans signaling counteracts STAT3 control of experimental inflammatory arthritis. J Immunol. (2008) 182:61322. doi: 10.4049/jimmunol.182.1.613

110. Hata H, Sakaguchi N, Yoshitomi H, Iwakura Y, Sekikawa K, Azuma Y, et al. Distinct contribution of IL-6, TNF-alpha, IL-1, and IL-10 to T cellmediated spontaneous autoimmune arthritis in mice. J Clin Invest. (2004) 114:582-8. doi: 10.1172/JCI200421795

111. Wong PKK, Quinn JMW, Sims NA, van Nieuwenhuijze A, Campbell IK, Wicks IP. Interleukin-6 modulates production of $\mathrm{T}$ lymphocyte-derived cytokines in antigen-induced arthritis and drives inflammation-induced osteoclastogenesis. Arthritis Rheum. (2006) 54:158-68. doi: 10.1002/art.21537

112. Walch-Rückheim B, Mavrova R, Henning M, Vicinus B, Kim Y-J, Bohle RM, et al. Stromal fibroblasts induce CCL20 through IL6/C/EBP $\beta$ to support the recruitment of Th17 cells during cervical cancer progression. Cancer Res. (2015) 75:5248-59. doi: 10.1158/0008-5472.CAN-15-0732

113. Denton CP, Ong VH, Xu S, Chen-Harris H, Modrusan Z, Lafyatis R, et al. Therapeutic interleukin- 6 blockade reverses transforming growth factor-beta pathway activation in dermal fibroblasts: insights from the faSScinate clinical trial in systemic sclerosis. Ann Rheum Dis. (2018) 77:1362-71. doi: 10.1136/annrheumdis-2018-213031

114. Le T-TT, Karmouty-Quintana H, Melicoff E, Le T-TT, Weng T, Chen N$\mathrm{Y}$, et al. Blockade of IL-6 trans signaling attenuates pulmonary fibrosis. $J$ Immunol. (2014) 193:3755-68. doi: 10.4049/jimmunol.1302470

115. Ma F, Li Y, Jia L, Han Y, Cheng J, Li H, et al. Macrophage-stimulated cardiac fibroblast production of IL-6 is essential for TGF $\beta /$ Smad activation and cardiac fibrosis induced by angiotensin II. PLOS ONE. (2012) 7:e35144. doi: 10.1371/journal.pone.0035144

116. Meléndez GC, McLarty JL, Levick SP, Du Y, Janicki JS, Brower GL. Interleukin 6 mediates myocardial fibrosis, concentric hypertrophy, and diastolic dysfunction in rats. Hypertension. (2010) 56:225-31. doi: 10.1161/HYPERTENSIONAHA.109.148635

117. Broxmeyer HE, Bruns HA, Zhang S, Cooper S, Hangoc G, McKenzie ANJ, et al. Th1 cells regulate hematopoietic progenitor cell homeostasis by production of oncostatin M. Immunity. (2002) 16:815-25. doi: 10.1016/S1074-7613(02)00319-9

118. Tanaka M, Hirabayashi Y, Sekiguchi T, Inoue T, Katsuki M, Miyajima A. Targeted disruption of oncostatin $\mathrm{M}$ receptor results in altered hematopoiesis. Blood. (2003) 102:3154-62. doi: 10.1182/blood-2003-02-0367

119. Minehata K-I, Takeuchi M, Hirabayashi Y, Inoue T, Donovan P, Tanaka M, et al. Oncostatin $\mathrm{M}$ maintains the hematopoietic microenvironment and retains hematopoietic progenitors in the bone marrow. Int J Hematol. (2006) 84:319-27. doi: 10.1532/IJH97.06090

120. Sato F, Miyaoka Y, Miyajima A, Tanaka M. Oncostatin M maintains the hematopoietic microenvironment in the bone marrow by modulating adipogenesis and osteogenesis. PLoS ONE. (2014) 9:e116209. doi: 10.1371/journal.pone.0116209

121. Hoermann G, Cerny-Reiterer S, Sadovnik I, Müllauer L, Bilban M, Gröger $\mathrm{M}$, et al. Oncostatin $\mathrm{M}$ is a FIP1L1/PDGFRA-dependent mediator of 
cytokine production in chronic eosinophilic leukemia. Allergy. (2013) 68:713-23. doi: 10.1111/all.12139

122. Hohensinner PJ, Kaun C, Rychli K, Niessner A, Pfaffenberger S, Rega $G$, et al. The inflammatory mediator oncostatin $M$ induces stromal derived factor-1 in human adult cardiac cells. FASEB J. (2009) 23:77482. doi: 10.1096/fj.08-108035

123. Lee MJ, Song HY, Kim MR, Sung S-M, Jung JS, Kim JH. Oncostatin $M$ stimulates expression of stromal-derived factor-1 in human mesenchymal stem cells. Int J Biochem Cell Biol. (2007) 39:650-9. doi: 10.1016/j.biocel.2006.11.003

124. Walker EC, Johnson RW, Hu Y, Brennan HJ, Poulton IJ, Zhang J-G, et al. Murine oncostatin $\mathrm{M}$ acts via leukemia inhibitory factor receptor to phosphorylate signal transducer and activator of transcription 3 (STAT3) but not STAT1, an effect that protects bone mass. J Biol Chem. (2016) 291:21703-16. doi: 10.1074/jbc.M116.748483

125. Walker EC, McGregor NE, Poulton IJ, Solano M, Pompolo S, Fernandes TJ, et al. Oncostatin $\mathrm{M}$ promotes bone formation independently of resorption when signaling through leukemia inhibitory factor receptor in mice. J Clin Invest. (2010) 120:582-92. doi: 10.1172/JCI40568

126. Guihard P, Danger Y, Brounais B, David E, Brion R, Delecrin J, et al. Induction of osteogenesis in mesenchymal stem cells by activated monocytes/macrophages depends on oncostatin M signaling. Stem Cells. (2012) 30:762-72. doi: 10.1002/stem.1040

127. Guihard P, Boutet M-A, Royer BB-L, Gamblin A-L, Amiaud J, Renaud A, et al. Oncostatin $\mathrm{M}$, an inflammatory cytokine produced by macrophages, supports intramembranous bone healing in a mouse model of tibia injury. Am J Pathol. (2015) 185:765-75. doi: 10.1016/j.ajpath.2014.11.008

128. Johnson RW, Brennan HJ, Vrahnas C, Poulton IJ, McGregor NE, Standal T, et al. The primary function of gp130 signaling in osteoblasts is to maintain bone formation and strength, rather than promote osteoclast formation. $J$ Bone Miner Res. (2014) 29:1492-505. doi: 10.1002/jbmr.2159

129. Nicolaidou V, Wong MM, Redpath AN, Ersek A, Baban DF, Williams LM, et al. Monocytes induce STAT3 activation in human mesenchymal stem cells to promote osteoblast formation. PLoS ONE. (2012) 7:e3987116. doi: 10.1371/journal.pone.0039871

130. Fernandes TJ, Hodge JM, Singh PP, Eeles DG, Collier FM, Holten I, et al. Cord blood-derived macrophage-lineage cells rapidly stimulate osteoblastic maturation in mesenchymal stem cells in a glycoprotein-130 dependent manner. PLoS ONE. (2013) 8:e73266-13. doi: 10.1371/journal.pone.0073266

131. Müller TA, Grundler R, Istvanffy R, Rudelius M, Hennighausen L, Illert $\mathrm{AL}$, et al. Lineage-specific STAT5 target gene activation in hematopoietic progenitor cells predicts the FLT3(+)-mediated leukemic phenotype. Leukemia. (2016) 30:1725-33. doi: 10.1038/leu.2016.72

132. Schwaller J, Parganas E, Wang D, Cain D, Aster JC, Williams IR, et al. Stat 5 is essential for the myelo- and lymphoproliferative disease induced by TEL/JAK2. Mol Cell. (2000) 6:693-704. doi: 10.1016/S1097-2765(00)00067-8

133. Hui W, Cawston TE, Richards CD, Rowan AD. A model of inflammatory arthritis highlights a role for oncostatin $\mathrm{M}$ in pro-inflammatory cytokineinduced bone destruction via RANK/RANKL. Arthritis Res Ther. (2005) 7:R57-64. doi: 10.1186/ar1460

134. Langdon C, Kerr C, Hassen M, Hara T, Arsenault AL, Richards CD. Murine oncostatin $\mathrm{M}$ stimulates mouse synovial fibroblasts in vitro and induces inflammation and destruction in mouse joints in vivo. Am J Pathol. (2000) 157:1187-96. doi: 10.1016/S0002-9440(10)64634-2

135. Hui W, Rowan AD, Richards CD, Cawston TE. Oncostatin M in combination with tumor necrosis factor alpha induces cartilage damage and matrix metalloproteinase expression in vitro and in vivo. Arthritis Rheum. (2003) 48:3404-18. doi: 10.1002/art.11333

136. Plater-Zyberk C, Buckton J, Thompson S, Spaull J, Zanders E, Papworth J, et al. Amelioration of arthritis in two murine models using antibodies to oncostatin M. Arthritis Rheum. (2001) 44:2697702. doi: 10.1002/1529-0131(200111)44:11<2697::AID-ART450>3.0.CO;2-\#

137. Langdon C, Leith J, Smith F, Richards CD. Oncostatin M stimulates monocyte chemoattractant protein-1- and interleukin-1-induced matrix metalloproteinase-1 production by human synovial fibroblasts in vitro. Arthritis Rheum. (1997) 40:2139-46. doi: 10.1002/art.1780401207

138. Fearon U, Mullan R, Markham T, Connolly M, Sullivan S, Poole AR, et al. Oncostatin $\mathrm{M}$ induces angiogenesis and cartilage degradation in rheumatoid arthritis synovial tissue and human cartilage cocultures. Arthritis Rheum. (2006) 54:3152-62. doi: 10.1002/art.22161

139. Hintzen C, Quaiser S, Pap T, Heinrich PC, Hermanns HM. Induction of CCL13 expression in synovial fibroblasts highlights a significant role of oncostatin M in rheumatoid arthritis. Arthritis Rheum. (2009) 60:193243. doi: 10.1002/art.24602

140. Cawston TE, Curry VA, Summers CA, Clark IM, Riley GP, Life PF, et al. The role of oncostatin $M$ in animal and human connective tissue collagen turnover and its localization within the rheumatoid joint. Arthritis Rheum. (1998) 41:176071. doi: 10.1002/1529-0131(199810)41:10<1760::AID-ART8>3.0.CO;2-M

141. Richards CD, Shoyab M, Brown TJ, Gauldie J. Selective regulation of metalloproteinase inhibitor (TIMP-1) by oncostatin $\mathrm{M}$ in fibroblasts in culture. J Immunol. (1993) 150:5596-603.

142. Moran EM, Mullan R, McCormick J, Connolly M, Sullivan O, FitzGerald $\mathrm{O}$, et al. Human rheumatoid arthritis tissue production of IL-17A drives matrix and cartilage degradation: synergy with tumour necrosis factor-alpha, Oncostatin M and response to biologic therapies. Arthritis Res Ther. (2009) 11:R113. doi: 10.1186/ar2772

143. Duncan MR, Hasan A, Berman B. Oncostatin M stimulates collagen and glycosaminoglycan production by cultured normal dermal fibroblasts: insensitivity of sclerodermal and keloidal fibroblasts. J Investig Dermatol. (1995) 104:128-33. doi: 10.1111/1523-1747.ep12613623

144. Ihn H, Tamaki K. Oncostatin M stimulates the growth of dermal fibroblasts via a mitogen-activated protein kinase-dependent pathway. J Immunol. (2000) 165:2149-55. doi: 10.4049/jimmunol.165.4.2149

145. Ihn H, LeRoy EC, Trojanowska M. Oncostatin M stimulates transcription of the human alpha2(I) collagen gene via the Sp1/Sp3-binding site. J Biol Chem. (1997) 272:24666-72. doi: 10.1074/jbc.272.39.24666

146. Hergovits S, Mais C, Haan C, Costa-Pereira AP, Hermanns HM. Oncostatin $M$ induces RIG-I and MDA5 expression and enhances the doublestranded RNA response in fibroblasts. J Cell Mol Med. (2017) 21:308799. doi: $10.1111 / \mathrm{jcmm} .13221$

147. Boniface K, Diveu C, Morel F, Pedretti N, Froger J, Ravon E, et al. Oncostatin $\mathrm{M}$ secreted by skin infiltrating $\mathrm{T}$ lymphocytes is a potent keratinocyte activator involved in skin inflammation. J Immunol. (2007) 178:461522. doi: 10.4049/jimmunol.178.7.4615

148. Pohin M, Guesdon W, Mekouo AAT, Rabeony H, Paris I, Atanassov H, et al. Oncostatin $\mathrm{M}$ overexpression induces skin inflammation but is not required in the mouse model of imiquimod-induced psoriasis-like inflammation. Eur J Immunol. (2016) 46:1737-51. doi: 10.1002/eji.201546216

149. Sanchez AL, Langdon CM, Akhtar M, Lu J, Richards CD, Bercik P, et al. Adenoviral transfer of the murine oncostatin $M$ gene suppresses dextransodium sulfate-induced colitis. I Interferon Cytokine Res. (2003) 23:193201. doi: 10.1089/107999003765027393

150. Mozaffarian A, Brewer AW, Trueblood ES, Luzina IG, Todd NW, Atamas SP, et al. Mechanisms of oncostatin M-induced pulmonary inflammation and fibrosis. J Immunol. (2008) 181:7243-53. doi: 10.4049/jimmunol.181.10.7243

151. Wong S, Botelho FM, Rodrigues RM, Richards CD. Oncostatin M overexpression induces matrix deposition, STAT3 activation, and SMAD1 Dysregulation in lungs of fibrosis-resistant BALB/c mice. Lab Investig. (2014) 94:1003-16. doi: 10.1038/labinvest.2014.81

152. Langdon C, Kerr C, Tong L, Richards CD. Oncostatin M regulates eotaxin expression in fibroblasts and eosinophilic inflammation in C57BL/6 mice. J Immunol. (2003) 170:548-55. doi: 10.4049/jimmunol.170.1.548

153. Ayaub EA, Dubey A, Imani J, Botelho F, Kolb MRJ, Richards CD, et al. Overexpression of OSM and IL-6 impacts the polarization of pro-fibrotic macrophages and the development of bleomycin-induced lung fibrosis. Sci Rep. (2017) 7:13281. doi: 10.1038/s41598-017-13511-z

154. Miller M, Beppu A, Rosenthal P, Pham A, Das S, Karta M, et al. Fstl1 promotes asthmatic airway remodeling by inducing oncostatin M. $J$ Immunol. (2015) 195:3546-56. doi: 10.4049/jimmunol.1501105

155. Fritz DK, Kerr C, Tong L, Smyth D, Richards CD. Oncostatin-M up-regulates VCAM-1 and synergizes with IL-4 in eotaxin expression: involvement of STAT6. J Immunol. (2006) 176:4352-60. doi: 10.4049/ jimmunol.176.7.4352

156. Machiyama T, So T, Okuyama Y, Kobayashi S, Phung HT, Asao A, et al. TNF receptor associated factor 5 controls oncostatin M-mediated 
lung inflammation. Biochem Biophys Res Commun. (2018) 499:544550. doi: 10.1016/j.bbrc.2018.03.186

157. Mähler $\mathrm{M}$, Bristol IJ, Leiter $\mathrm{EH}$, Workman $\mathrm{AE}$, Birkenmeier $\mathrm{EH}$, Elson CO, et al. Differential susceptibility of inbred mouse strains to dextran sulfate sodium-induced colitis. Am J Physiol. (1998) 274:G54451. doi: 10.1152/ajpgi.1998.274.3.G544

158. Beckwith J, Cong Y, Sundberg JP, Elson CO, Leiter EH. Cdcs1, a major colitogenic locus in mice, regulates innate and adaptive immune response to enteric bacterial antigens. Gastroenterology. (2005) 129:147384. doi: 10.1053/j.gastro.2005.07.057

159. Borm MEA, He J, Kelsall B, Peña AS, Strober W, Bouma G. A major quantitative trait locus on mouse chromosome 3 is involved in disease susceptibility in different colitis models. Gastroenterology. (2005) 128:7485. doi: $10.1053 /$ j.gastro.2004.10.044

160. Farmer MA, Sundberg JP, Bristol IJ, Churchill GA, Li R, Elson CO, et al. A major quantitative trait locus on chromosome 3 controls colitis severity in IL-10-deficient mice. Proc Natl Acad Sci USA. (2001) 98:138205. doi: $10.1073 /$ pnas. 241258698

161. Buettner M, Bleich A. Mapping colitis susceptibility in mouse models: distal chromosome 3 contains major loci related to Cdcs1. Physiol Genomics. (2013) 45:925-30. doi: 10.1152/physiolgenomics.00084.2013

162. Boulard O, Kirchberger S, Royston DJ, Maloy KJ, Powrie FM. Identification of a genetic locus controlling bacteria-driven colitis and associated cancer through effects on innate inflammation. J Exp Med. (2012) 209:130924. doi: $10.1084 / \mathrm{jem} .20120239$

163. Bleich A, Büchler G, Beckwith J, Petell LM, Affourtit JP, King BL, et al. Cdcs1 a major colitis susceptibility locus in mice; subcongenic analysis reveals genetic complexity. Inflamm Bowel Dis. (2010) 16:76575. doi: $10.1002 /$ ibd. 21146

164. Ermann J, Garrett WS, Kuchroo J, Rourida K, Glickman JN, Bleich A, et al. Severity of innate immune-mediated colitis is controlled by the cytokine deficiency-induced colitis susceptibility-1 (Cdcs1) locus. Proc Natl Acad Sci USA. (2011) 108:7137-41. doi: 10.1073/pnas.1104234108

165. Ryzhakov G, West NR, Franchini F, Clare S, Ilott NE, Sansom SN, et al. Alpha kinase 1 controls intestinal inflammation by suppressing the IL-12/Th1 axis. Nat Commun. (2018) 9:3797. doi: 10.1038/s41467-018-06085-5

166. Jostins L, Ripke S, Weersma RK, Duerr RH, McGovern DP, Hui $\mathrm{KY}$, et al. Host-microbe interactions have shaped the genetic architecture of inflammatory bowel disease. Nature. (2012) 491:119-24. doi: 10.1038/nature11582

167. Liu JZ, van Sommeren S, Huang H, Ng SC, Alberts R, Takahashi A, et al. Association analyses identify 38 susceptibility loci for inflammatory bowel disease and highlight shared genetic risk across populations. Nat Genet. (2015) 47:979-86. doi: 10.1038/ng.3359

168. Gharavi AG, Kiryluk K, Choi M, Li Y, Hou P, Xie J, et al. Genome-wide association study identifies susceptibility loci for IgA nephropathy. Nat Genet. (2011) 43:321-7. doi: 10.1038/ng.787

169. Cook S, Ng B, Dong J, Viswanathan S, DAgostino G, Widjaja A, et al. IL-11 is a Therapeutic Target in Idiopathic Pulmonary Fibrosis. bioRxiv (2018). doi: 10.1101/336537

170. Lee CG, Hartl D, Matsuura H, Dunlop FM, Scotney PD, Fabri LJ, et al. Endogenous IL-11 signaling is essential in Th2- and IL-13-induced inflammation and mucus production. Am J Respir Cell Mol Biol. (2008) 39:739-46. doi: 10.1165/rcmb.2008-0053OC

171. Tang W, Geba GP, Zheng T, Ray P, Homer RJ, Kuhn C, et al. Targeted expression of IL-11 in the murine airway causes lymphocytic inflammation, bronchial remodeling, and airways obstruction. J Clin Invest. (1996) 98:284553. doi: 10.1172/JCI119113

172. Waring PM, Waring LJ, Billington T, Metcalf D. Leukemia inhibitory factor protects against experimental lethal Escherichia coli septic shock in mice. Proc Natl Acad Sci USA. (1995) 92:1337-41. doi: 10.1073/pnas.92.5.1337

173. Weber MA, Schnyder-Candrian S, Schnyder B, Quesniaux V, Poli V, Stewart $\mathrm{CL}$, et al. Endogenous leukemia inhibitory factor attenuates endotoxin response. Lab Invest. (2005) 85:276-84. doi: 10.1038/labinvest.3700216

174. Trepicchio WL, Bozza M, Pedneault G, Dorner AJ. Recombinant human IL-11 attenuates the inflammatory response through down-regulation of proinflammatory cytokine release and nitric oxide production. J Immunol. (1996) $157: 3627-34$.
175. Maeshima K, Takahashi T, Nakahira K, Shimizu H, Fujii H, Katayama H, et al. A protective role of interleukin 11 on hepatic injury in acute endotoxemia. Shock. (2004) 21:134-8. doi: 10.1097/01.shk.0000103386.98235.f6

176. Bozza M, Bliss JL, Maylor R, Erickson J, Donnelly L, Bouchard P, et al. Interleukin-11 reduces T-cell-dependent experimental liver injury in mice. Hepatology. (1999) 30:1441-7. doi: 10.1002/hep.510300616

177. Shimizu T, Shiratori K, Sawada T, Kobayashi M, Hayashi N, Saotome H, et al. Recombinant human interleukin-11 decreases severity of acute necrotizing pancreatitis in mice. Pancreas. (2000) 21:134-40. doi: 10.1097/00006676-200008000-00005

178. Gao W, Thompson L, Zhou Q, Putheti P, Fahmy TM, Strom TB, et al. Treg versus Th17 lymphocyte lineages are cross-regulated by LIF versus IL-6. Cell Cycle. (2009) 8:1444-50. doi: 10.4161/cc.8.9.8348

179. Cao W, Yang Y, Wang Z, Liu A, Fang L, Wu F, et al. Leukemia inhibitory factor inhibits $\mathrm{T}$ helper 17 cell differentiation and confers treatment effects of neural progenitor cell therapy in autoimmune disease. Immunity. (2011) 35:273-84. doi: 10.1016/j.immuni.2011.06.011

180. Curti A, Ratta M, Corinti S, Girolomoni G, Ricci F, Tazzari P, et al. Interleukin-11 induces Th2 polarization of human CD4(+) T cells. Blood. (2001) 97:2758-63. doi: 10.1182/blood.V97.9.2758

181. Bozza M, Bliss JL, Dorner AJ, Trepicchio WL. Interleukin-11 modulates Th1/Th2 cytokine production from activated CD4+ T cells. J Interferon Cytokine Res. (2001) 21:21-30. doi: 10.1089/107999001459123

182. Hill GR, Cooke KR, Teshima T, Crawford JM, Keith JC, Brinson YS, et al. Interleukin-11 promotes $\mathrm{T}$ cell polarization and prevents acute graft-versushost disease after allogeneic bone marrow transplantation. J Clin Invest. (1998) 102:115-23. doi: 10.1172/JCI3132

183. Chen Q, Rabach L, Noble P, Zheng T, Lee CG, Homer RJ, et al. IL-11 receptor alpha in the pathogenesis of IL-13-induced inflammation and remodeling. $J$ Immunol. (2005) 174:2305-13. doi: 10.4049/jimmunol.174.4.2305

184. Ernst M, Najdovska M, Grail D, Lundgren-May T, Buchert M, Tye H, et al. STAT3 and STAT1 mediate IL-11-dependent and inflammation-associated gastric tumorigenesis in gp130 receptor mutant mice. J Clin Invest. (2008) 118:1727-38. doi: 10.1172/JCI34944

185. Putoczki TL, Thiem S, Loving A, Busuttil RA, Wilson NJ, Ziegler PK, et al. Interleukin-11 is the dominant IL-6 family cytokine during gastrointestinal tumorigenesis and can be targeted therapeutically. Cancer Cell. (2013) 24:257-71. doi: 10.1016/j.ccr.2013.06.017

186. Johnstone CN, Chand A, Putoczki TL, Ernst M. Emerging roles for IL-11 signaling in cancer development and progression: focus on breast cancer. Cytokine Growth Factor Rev. (2015) 26:489-98. doi: 10.1016/j.cytogfr.2015.07.015

187. West NR, McCuaig S, Franchini F, Powrie F. Emerging cytokine networks in colorectal cancer. Nat Rev Immunol. (2015) 15:615-29. doi: 10.1038/nri3896

188. Juan TS-C, Bolon B, Lindberg RA, Sun Y, Van G, Fletcher FA. Mice overexpressing murine oncostatin M (OSM) exhibit changes in hematopoietic and other organs that are distinct from those of mice overexpressing human OSM or bovine OSM. Vet Pathol. (2009) 46:124-37. doi: 10.1354/ vp.46-1-124

189. Clegg CH, Rulffes JT, Wallace PM, Haugen HS. Regulation of an extrathymic T-cell development pathway by oncostatin M. Nature. (1996) 384:2613. doi: $10.1038 / 384261 \mathrm{a} 0$

190. Boileau C, Houde M, Dulude G, Clegg CH, Perreault C. Regulation of extrathymic $\mathrm{T}$ cell development and turnover by oncostatin M. J Immunol. (2000) 164:5713-20. doi: 10.4049/jimmunol.164.11 .5713

191. Shen MM, Skoda RC, Cardiff RD, Campos-Torres J, Leder P, Ornitz DM. Expression of LIF in transgenic mice results in altered thymic epithelium and apparent interconversion of thymic and lymph node morphologies. EMBO J. (1994) 13:1375-85. doi: 10.1002/j.1460-2075.1994. tb06391.x

192. Louis I, Dulude G, Corneau S, Brochu S, Boileau C, Meunier C, et al. Changes in the lymph node microenvironment induced by oncostatin M. Blood. (2003) 102:1397-404. doi: 10.1182/blood-2003-01-0316

193. Metcalf D, Gearing DP. A myelosclerotic syndrome in mice engrafted with cells producing high levels of leukemia inhibitory factor (LIF). Leukemia. (1989) 3:847-52. 
194. Malik N, Haugen HS, Modrell B, Shoyab M, Clegg CH. Developmental abnormalities in mice transgenic for bovine oncostatin M. Mol Cell Biol. (1995) 15:2349-58. doi: 10.1128/MCB.15.5.2349

195. Yoshida H, Hunter CA. The immunobiology of interleukin-27. Annu Rev Immunol. (2015) 33:417-43. doi: 10.1146/annurev-immunol-032414-112134

196. Lucas S, Ghilardi N, Li J, de Sauvage FJ. IL-27 regulates IL-12 responsiveness of naive $\mathrm{CD} 4+\mathrm{T}$ cells through Stat1-dependent and independent mechanisms. Proc Natl Acad Sci USA. (2003) 100:1504752. doi: $10.1073 /$ pnas. 2536517100

197. Chen Q, Ghilardi N, Wang H, Baker T, Xie MH, Gurney A, et al. Development of Th1-type immune responses requires the type I cytokine receptor TCCR. Nature. (2000) 407:916-20. doi: 10.1038/35038103

198. Takeda A, Hamano S, Yamanaka A, Hanada T, Ishibashi T, Mak TW, et al. Cutting edge: role of IL-27/WSX-1 signaling for induction of T-bet through activation of STAT1 during initial Th1 commitment. J Immunol. (2003) 170:4886-90. doi: 10.4049/jimmunol.170.10.4886

199. Yoshida H, Hamano S, Senaldi G, Covey T, Faggioni R, Mu S, et al. WSX1 is required for the initiation of Th1 responses and resistance to $\mathrm{L}$. major infection. Immunity. (2001) 15:569-78. doi: 10.1016/S1074-7613(01)00206-0

200. Hall AO, Beiting DP, Tato C, John B, Oldenhove G, Lombana CG, et al. The cytokines interleukin 27 and interferon- $\gamma$ promote distinct Treg cell populations required to limit infection-induced pathology. Immunity. (2012) 37:511-23. doi: 10.1016/j.immuni.2012.06.014

201. Wang H, Meng R, Li Z, Yang B, Liu Y, Huang F, et al. IL-27 induces the differentiation of Tr1-like cells from human naive CD4+ T cells via the phosphorylation of STAT1 and STAT3. Immunol Lett. (2011) 136:218. doi: 10.1016/j.imlet.2010.11.007

202. Awasthi A, Carrier Y, Peron JPS, Bettelli E, Kamanaka M, Flavell RA, et al. A dominant function for interleukin 27 in generating interleukin 10-producing anti-inflammatory T cells. Nat Immunol. (2007) 8:13809. doi: 10.1038/ni1541

203. Murugaiyan G, Mittal A, Lopez-Diego R, Maier LM, Anderson DE, Weiner HL. IL-27 is a key regulator of IL-10 and IL-17 production by human CD4+ T cells. J Immunol. (2009) 183:2435-43. doi: 10.4049/jimmunol.0900568

204. Pot C, Jin H, Awasthi A, Liu SM, Lai C-Y, Madan R, et al. Cutting edge: IL-27 induces the transcription factor c-Maf, cytokine IL-21, and the costimulatory receptor ICOS that coordinately act together to promote differentiation of IL-10-producing Tr1 cells. J Immunol. (2009) 183:797801. doi: 10.4049/jimmunol.0901233

205. Romano M, Sironi M, Toniatti C, Polentarutti N, Fruscella P, Ghezzi P, et al. Role of IL-6 and its soluble receptor in induction of chemokines and leukocyte recruitment. Immunity. (1997) 6:315-25. doi: 10.1016/S1074-7613(00)80334-9

206. Watson C, Whittaker S, Smith N, Vora AJ, Dumonde DC, Brown KA. IL-6 acts on endothelial cells to preferentially increase their adherence for lymphocytes. Clin Exp Immunol. (1996) 105:112-9. doi: 10.1046/j.1365-2249.1996.d01-717.x

207. Kerfoot SM, Raharjo E, Ho M, Kaur J, Serirom S, McCafferty DM, et al. Exclusive neutrophil recruitment with oncostatin $\mathrm{M}$ in a human system. Am J Pathol. (2001) 159:1531-9. doi: 10.1016/S0002-9440(10)62538-2

208. Yao L, Pan J, Setiadi H, Patel KD, McEver RP. Interleukin 4 or oncostatin $\mathrm{M}$ induces a prolonged increase in P-selectin mRNA and protein in human endothelial cells. J Exp Med. (1996) 184:81-92. doi: 10.1084/jem.184.1.81

209. Barksby HE, Hui W, Wappler I, Peters HH, Milner JM, Richards CD, et al. Interleukin-1 in combination with oncostatin $\mathrm{M}$ up-regulates multiple genes in chondrocytes: implications for cartilage destruction and repair. Arthritis Rheum. (2006) 54:540-50. doi: 10.1002/art.21574

210. Kok S-H, Hong C-Y, Kuo MY-P, Wang C-C, Hou K-L, Lin Y-T, et al. Oncostatin M-induced CCL2 transcription in osteoblastic cells is mediated by multiple levels of STAT-1 and STAT-3 signaling: an implication for the pathogenesis of arthritis. Arthritis Rheum. (2009) 60:1451-62. doi: 10.1002/art.24452

211. Stawski L, Trojanowska M. Oncostatin M and its role in fibrosis. Connect Tissue Res. (2018) 19:1-10. doi: 10.1080/03008207.2018.1500558

212. Nishimoto N, Kanakura $\mathrm{Y}$, Aozasa K, Johkoh T, Nakamura M, Nakano S, et al. Humanized anti-interleukin-6 receptor antibody treatment of multicentric Castleman disease. Blood. (2005) 106:2627-32. doi: 10.1182/blood-2004-12-4602

213. Nishimoto N, Yoshizaki K, Miyasaka N, Yamamoto K, Kawai S, Takeuchi T, et al. Treatment of rheumatoid arthritis with humanized anti-interleukin6 receptor antibody: a multicenter, double-blind, placebo-controlled trial. Arthritis Rheum. (2004) 50:1761-9. doi: 10.1002/art.20303

214. Villiger PM, Adler S, Kuchen S, Wermelinger F, Dan D, Fiege V, et al. Tocilizumab for induction and maintenance of remission in giant cell arteritis: a phase 2, randomised, double-blind, placebo-controlled trial. Lancet. (2016) 387:1921-7. doi: 10.1016/S0140-6736(16)00560-2

215. Bae S-C, Lee YH. Comparison of the efficacy and tolerability of tocilizumab, sarilumab, and sirukumab in patients with active rheumatoid arthritis: a Bayesian network meta-analysis of randomized controlled trials. Clin Rheumatol. (2018) 37:1471-9. doi: 10.1007/s10067-018-4006-5

216. De Benedetti F, Brunner HI, Ruperto N, Kenwright A, Wright S, Calvo I, et al. Randomized trial of tocilizumab in systemic juvenile idiopathic arthritis. $N$ Engl J Med. (2012) 367:2385-95. doi: 10.1056/NEJMoa1112802

217. Norelli M, Camisa B, Barbiera G, Falcone L, Purevdorj A, Genua M, et al. Monocyte-derived IL-1 and IL-6 are differentially required for cytokinerelease syndrome and neurotoxicity due to CAR T cells. Nature. (2018) 24:739-48. doi: 10.1038/s41591-018-0036-4

218. Choy EH, Bendit M, McAleer D, Liu F, Feeney M, Brett S, et al. Safety, tolerability, pharmacokinetics and pharmacodynamics of an antioncostatin M monoclonal antibody in rheumatoid arthritis: results from phase II randomized, placebo-controlled trials. Arthritis Res Ther. (2013) 15:R132. doi: 10.1186/ar4312

219. Moreland L, Gugliotti R, King K, Chase W, Weisman M, Greco T, et al. Results of a phase-I/II randomized, masked, placebo-controlled trial of recombinant human interleukin-11 (rhIL-11) in the treatment of subjects with active rheumatoid arthritis. Arthritis Res. (2001) 3:24752. doi: 10.1186/ar309

220. Schwartz DM, Kanno Y, Villarino A, Ward M, Gadina M, O'Shea JJ. JAK inhibition as a therapeutic strategy for immune and inflammatory diseases. Nat Rev Drug Discov. (2017) 16:843-62. doi: 10.1038/nrd.2017.267

Conflict of Interest Statement: NW is an employee of Genentech, Inc, and is an inventor on patents related to oncostatin $\mathrm{M}$.

Copyright (C) 2019 West. This is an open-access article distributed under the terms of the Creative Commons Attribution License (CC BY). The use, distribution or reproduction in other forums is permitted, provided the original author(s) and the copyright owner(s) are credited and that the original publication in this journal is cited, in accordance with accepted academic practice. No use, distribution or reproduction is permitted which does not comply with these terms. 